\title{
Unexpected new lizard from the Late Cretaceous of southern South America sheds light on Gondwanan squamate diversity
}

\author{
Agustín G. MARTINELLI ${ }^{1}$, Federico L. AGNOLÍN ${ }^{2,3}$ \& Martín D. EZCURRA ${ }^{1}$
}

\begin{abstract}
${ }^{1}$ Sección Paleontología de Vertebrados, CONICET-Museo Argentino de Ciencias Naturales 'Bernardino Rivadavia', Avenida Ángel Gallardo 470, C1405DJR, CABA, Argentina. agustin martinelli@yahoo.com. ar / martindezcurra@yahoo.com.ar. 22Laboratorio de Anatomía Comparada y Evolución de los Vertebrados, CONICET-Museo Argentino de Ciencias Naturales "Bernardino Rivadavia", Avenida Ángel Gallardo 470, C1405DJR, CABA, Argentina. fedeagnolin@yahoo.com.ar. ${ }^{3}$ Fundación de Historia Natural "Félix de Azara", Departamento de Ciencias Naturales y Antropología. CEBBAD - Universidad Maimónides. Hidalgo 775, C1405BDB, CABA, Argentina.
\end{abstract}

\begin{abstract}
The record of Cretaceous terrestrial lizards (Squamata) in South America is patchy, with seven species described from north-eastern and south-eastern Brazil, and few isolated records of iguanians and scincomorphans from the Argentinian Patagonia. Herein we describe a new genus and species of Cretaceous lizard, Paleochelco occultato gen. et sp. nov., based on a partial skull (MACN-Pv-N 120) discovered about three decades ago that was unnoticed in the Colección Paleovertebrados of the Museo Argentino de Ciencias Naturales "Bernardino Rivadavia". It comes from rocks of the Upper Cretaceous Bajo de la Carpa Formation (Neuquén Group) exposed at the Campus of the Universidad Nacional del Comahue, north of Neuquén City (Neuquén Province). The new taxon was included into a broad phylogenetic dataset of squamates and it was recovered around the base of Polyglyphanodontia in a constrained analysis using a total-evidence backbone. By contrast, the same, but topologically unconstrained analysis found Paleochelco occultato also around the base of Polyglyphanodontia but alternatively as the sister taxon to Polyglyphanodontia + Scleroglossa or as one of the sister taxa to the Mosasauria + Scleroglossa clade. The new finding, as well as other records from Argentina and Brazil, highlights a complex, still unrecovered, evolutionary history for lizards in the Mesozoic of South America.
\end{abstract}

Key words: Squamata, Patagonia, Neuquén Group, Upper Cretaceous.

Resumen: Un nuevo lagarto inesperado para el Cretácico Tardío del sur de América del Sur arroja luz sobre la diversidad de escamados gondwánicos. El registro de lagartos (Squamata) terrestres del Cretácico de América del Sur es escaso, con siete especies descritas para el noreste y sureste de Brasil, y unos pocos registros aislados de iguanios y escincomorfos de la Patagonia argentina. Aquí describimos un nuevo género y especie de lagarto cretácico, Paleochelco occultato gen. et sp. nov., basado en un cráneo parcial (MACNPv-N 120) descubierto hace más de tres décadas, que pasó desapercibido en la Colección Paleovertebrados del Museo Argentino de Ciencias Naturales "Bernardino Rivadavia". Este espécimen proviene de rocas del Cretácico Superior de la Formación Bajo de la Carpa (Grupo Neuquén), expuestas en el Campus de la Universidad Nacional del Comahue, al norte de la Ciudad de Neuquén (Provincia del Neuquén). El nuevo taxón se incluyó en una amplia matriz filogenética de Squamata y fue recuperado alrededor de la base de Polyglyphanodontia en un análisis con restricción topológica siguiendo una topología basada en evidencia total. En contraste, el mismo análisis, pero sin la restricción topológica, encontró a Paleochelco occultato también alrededor de la base de Polyglyphanodontia pero alternativamente como el taxón hermano de Polyglyphanodontia + Scleroglossa o como uno de los taxones hermanos del clado Mosasauria + Scleroglossa. El nuevo hallazgo, así como otros registros de Argentina y Brasil, destaca una historia evolutiva compleja, aún poco conocida, de los lagartos en el Mesozoico de América del Sur.

Palabras clave: Squamata, Patagonia, Grupo Neuquén, Cretácico Superior.

\section{INTRODUCTION}

Living lizards includes $\sim 7000$ species distributed in all continents, except Antarctica (Uetz et al., 2020). The term lizard refers to a paraphyletic assemblage of mostly terrestrial limbed squa- mates (e.g., iguanians, lacertoids, gekkotans), thus excluding snakes and amphisbaenians. All these extant limbed and limbless taxa plus some completely extinct lineages (e.g., mosasaurs) constitute the clade Squamata (e.g., Gauthier \& de Queiroz, 1998; Pyron, 2017; Simões et al., 2018; 
Sues, 2019; Simões \& Pyron, 2021). Squamates have a patchy Mesozoic fossil record, especially during the Triassic and Jurassic periods, when they probably originated and had their first diversification event (e.g., Evans \& Jones, 2010; Simões et al., 2017, 2018). The lizard record is also unevenly distributed in Mesozoic rocks, with considerably abundant and taxonomically diverse occurrences in the Cretaceous of Laurasia (e.g., Borsuk-Białynicka \& Moody, 1984; Gao \& Norell, 1998, 2000; Nydam et al., 2000; Nydam \& Cifelli, 2002; Conrad \& Norell, 2007; Evans \& Wang, 2010; DeMar Jr et al., 2017; HerreraFlores et al., 2021). Conversely, the record in the southern continents is still scanty and the sampling bias coupled with the incompleteness of most hitherto known lizard specimens hamper solid interpretations on early lizard distribution and diversification (Benson et al., 2013; Cleary et al., 2018). For instance, the most diverse Mesozoic record of Gondwanan lizards is from the Cretaceous of Brazil, including a few relatively complete specimens (e.g., Simões et al., 2017; Bittencourt et al., 2020), namely Tijubina pontei, Olindalacerta brasiliensis, and Calanguban alamoi from the Aptian-Albian Crato Formation (Araripe Basin; Bonfim-Júnior \& Marques, 1997; Evans \& Yabumoto, 1998; Bonfim-Júnior \& Rocha-Barbosa, 2006; Simões, 2012; Simões et al., 2015a, 2017), Neokotus sanfranciscanus from the Valanginian Quiricó Formation (Sanfranciscana Basin; Bittencourt et al., 2020), Gueragama sulamericana from the TuronianCampanian Goio-Erê Formation (Bauru Basin; Simões et al., 2015b), Brasiliguana prudentis (Nava \& Martinelli, 2011) and a lizard-like squamate (Candeiro et al., 2009) from the Campanian Adamantina Formation (Bauru Basin), and Pristiguana brasiliensis from the Maastrichtian Serra da Galga Formation (Bauru Basin; Estes \& Price, 1973) (Fig. 1). In contrast, Mesozoic lizards from Argentina include a few scattered remains collected in Upper Cretaceous units (Candeleros, Anacleto, and Los Alamitos formations) and identified as unnamed iguanians and scincomorphans (Apesteguía et al., 2005; Albino, 2002, 2007, 2011; Brizuela \& Albino, 2011; Albino \& Brizuela, 2014) (Fig. 1). Although in the last years the number of named lizard species and records grew considerably in South America, their phylogenetic and taxonomic affinities remain unclear for most of these occurrences, especially those based on fragmentary and/or isolated material (Albino \& Brizuela, 2014; Simões et al., 2015a, 2017). For the rest of Gondwana, lizard or lizard-like remains are also sparse, including iguanians and scincomorphs that come from the Middle Jurassic of India (Evans et al., 2002), the Upper Jurassic of Tanzania (Zils et al., 1995), the Lower Cretaceous of Morocco (Richter, 1994; Broschinski \& Sigogneau-Russell, 1996) and South Africa (Ross et al., 1999), and the latest Cretaceous of Madagascar (the partially complete skeleton of the possible cordylid Konkasaurus mahalana; Krause et al., 2003).

The aim of this contribution is to describe a new genus and species of fossil lizard based on a partial skull (MACN-Pv-N 120) from the Upper Cretaceous Bajo de la Carpa Formation (Neuquén Group, Neuquén Basin). This specimen was collected approximately 35 years ago in the historical locality "Boca del Sapo", corresponding to outcrops located north of the Neuquén City, now the campus and vicinity of the Universidad Nacional del Comahue (Woodward, 1896; Gasparini, 1971; Bonaparte, 1991), Neuquén Province (Patagonia, Argentina). MACN-Pv-N 120 remained unnoticed in a small box together with bone fragments of notosuchian mesoeucrocodylians and a tooth of an abelisaurid theropod collected and donated by Oscar de Ferrariis (former Director of the Museum of the Universidad Nacional del Comahue) in the 1980s to the Colección Paleovertebrados of the Museo Argentino de Ciencias Naturales "Bernardino Rivadavia". The new lizard specimen remained unnoticed in the collection possibly due to its small size and fairly weathered surface. It was a surprising finding during a revision of this collection and, thus, was further prepared. Although the skull is incomplete, it is currently by far the most informative squamate lizard from the Mesozoic of Patagonia and the first named Mesozoic lizard from Argentina.

\section{MATERIALS AND METHODS}

\section{Geological and Paleontological Settings}

MACN-Pv-N 120 was collected from the campus of the Universidad Nacional del Comahue, in Neuquén city, Neuquén Province, Argentina. This outcrop of the campus of the Universidad Nacional del Comahue together with a nearby series of cliffs in the north of Neuquén City are referred as the "Boca del Sapo" locality and has yielded several fossil remains since the late XIX century (Woodward, 1896; Gasparini, 1971; Bonaparte, 1991). MACN-Pv-N 120 comes from the Bajo de la Carpa Formation, Río Colorado Subgroup, Neuquén Group, which extends along 
South American Cretaceous lizards

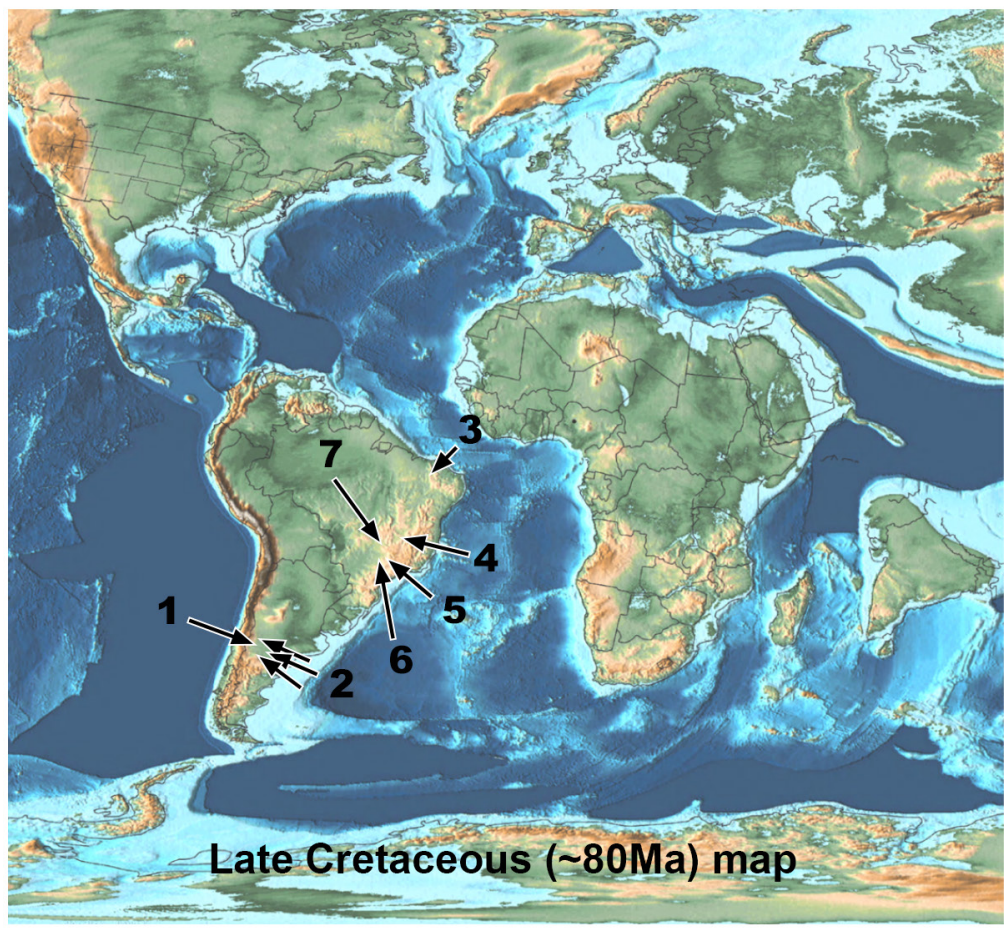

\section{Argentina}

1 - Paleochelco occultato

gen. et sp. nov.

(Santonian, Bajo de la Carpa Fm)

2 - Unnamed iguanians and

scincomorphans

(Cenomanian to Maastrichtian;

Candeleros, Anacleto, and

Los Alamitos fms)

\section{Brazil}

3 - Tijubina pontei,

Olindalacerta brasiliensis,

Calanguban alamoi

(Aptian-Albian, Crato Fm)

4 - Neokotus sanfranciscanus

(Valanginian, Quiricó Fm)

5 - Brasiliguana prudentis

and a lizard-like squamate

(Santonian-Campanian,

Adamantina $\mathrm{Fm}$ )

6 - Gueragama sulamericana

(Turonian-Campanian,

Goio-Erê Fm)

7 - Pristiguana brasiliensis

(Maastrichtian,

Serra da Galga Fm)

Fig. 1. Late Cretaceous map (modified from Scotese, 2013) with the record of South American Cretaceous lizards (excluding mosasaurs). The holotype of Paleochelco occultato gen. et sp. nov. was found at the Neuquén city, Neuquén Province, northern Patagonia, Argentina.

the west and north of Neuquén, west of Río Negro, and south of Mendoza provinces (e.g., Ramos, 1981; Leanza \& Hugo, 2001; Garrido, 2010). The Bajo de la Carpa Formation conformably overlies the Plottier Formation and is conformably covered by the Anacleto Formation. The Bajo de la Carpa Formation reaches up to $\sim 145 \mathrm{~m}$ of thickness in some areas and is mainly composed of coarse-grained, light red to pink sandstones intercalated by thin reddish siltstones and claystones (Leanza \& Hugo, 1997; Garrido, 2010). Paleosols, siliceous geodes, chemical nodules, and rain drops marks are very abundant throughout the unit (Rodríguez et al., 2007). Most sediments of this unit were deposited in low-sinuosity fluvial paleoenvironments (Garrido, 2010); however, some layers at the "Boca del Sapo" locality were interpreted as aeolian in origin (Sánchez et al., 2006; Rodríguez et al., 2007; Filippi et al., 2015). The Bajo de la Carpa Formation was deposited under warm and semiarid climatic conditions (Garrido, 2010).

The fossil tetrapod content of this unit is highly diverse, but with conspicuous differenc- es along the fossil-bearing outcrops distributed throughout the Neuquén Basin (e.g., Bonaparte, 1991; Garrido, 2010; Porfiri et al., 2018). The "Boca del Sapo" locality in Neuquén Province, where MACN-Pv-N 120 was found, and the "Paso Córdoba (or Paso Córdova)" locality, near General Roca City, at Río Negro Province, share a similar fauna, with similar facies of possibly coeval age. Both localities yielded notosuchian mesoeucrocodylians (Notosuchus terrestris, Comahuesuchus brachybucalis, and baurusuchids-Wargosuchus australis in "Boca del Sapo" and Baurusuchidae indet. in "Paso Córdoba"-; Woodward, 1896; Gasparini, 1971; Bonaparte, 1991; Martinelli, 2003; Pol, 2005; Martinelli \& Pais, 2008; Leardi et al., 2018), snakes (Dinilysia patagonica; Woodward, 1901; Bonaparte, 1991), and small-sized theropod dinosaurs (the abelisauroid Velocisaurus unicus and alvarezsaurids-Alvarezsaurus calvoi in "Boca del Sapo" and Achillesaurus manazzonei in "Paso Córdoba"-; Bonaparte, 1991; Martinelli \& Vera, 2007; Brissón Egli et al., 2016). The "Boca del Sapo" locality also includes the mesoeucrocody- 
lians Microsuchus schilleri (Woodward, 1896; Leardi et al., 2015), Neuquensuchus universitas (Fiorelli \& Calvo, 2007; Lio et al., 2018), and peirosaurids (Fiorelli, 2010), the enantiornithine Neuquenornis volans (Chiappe \& Calvo, 1994) and egg-clutches with embryos referred to this clade (Schweitzer et al., 2002), and the ornithuromorph Patagopteryx deferrariisi (Alvarenga \& Bonaparte, 1992). The mesoeucrocodylian Cynodontosuchus rothi might have been found at this locality (Woodward, 1896), but a precise location is unknown. A caudal vertebra of a medium-sized indeterminate abelisaurid (Ezcurra \& Méndez, 2009) was reported as possibly recovered at the "Paso Córdoba" locality. This specimen aside, the faunal content of the "Boca del Sapo" and "Paso Córdoba" localities is almost entirely composed of small-sized animals.

In other outcrops of the Bajo de la Carpa Formation, the aforementioned species are not yet recovered but instead its tetrapod content includes titanosaurs (Bonitasaura salgadoi, Rinconsaurus caudamirus, Traukutitan eocaudata, Overosaurus paradasorum; Calvo \& González Riga, 2003; Apesteguía, 2004; Juárez Valieri \& Calvo, 2011; Coria et al., 2013), megaraptoran (Tratayenia rosalesi; Porfiri et al., 2018) and abelisaurid (Viavenator exxoni and Llukalkan aliocranianus; Filippi et al., 2016; Méndez et al., 2018; Gianechini et al., 2021) theropods, ornithopods (Mahuidacursor lipanglef; Jiménez-Gomis et al., 2018; Cruzado-Caballero et al., 2019), dinosaur eggshells (Calvo et al., 1997; Garrido \& Calvo, 2004; Cruzado-Caballero et $a l ., 2016)$, mesoeucrocodylians (the peirosaurids Gasparinisuchus peirosauroides, Kinesuchus overoi, and Barrosasuchus neuquenianus; Martinelli et al., 2012; Fillippi et al., 2018; Coria et al., 2019), and turtles (Lomalatachelys neuquina; Lapparent de Broin \& de la Fuente, 2001). The conspicuous faunal differences between localities can be related to different depositional settings along the basin and/or different ages of deposition (Sánchez et al., 2006; Rodríguez et al., 2007; Garrido, 2010; Filippi et al., 2015). The age of the Bajo de la Carpa Formation is constrained to the Santonian Stage of the Upper Cretaceous (Bonaparte, 1991; Hugo \& Leanza, 2001; Leanza et al., 2004; Rodríguez et al., 2007; Garrido, 2010).

\section{Computed Tomography}

MACN-Pv-N 120 was scanned at the Servicio de Microtomografía of the Facultad de Odontología of the Universidad de Buenos
Aires, using a CT scanner Sky Scan 1272. The micro-computed tomography $(\mu \mathrm{CT})$ dataset has a total of 1502 slices with a voxel size of 10.67038 $\mu \mathrm{m}$; it was acquired with a voltage of $90 \mathrm{kV}$ and current of $111 \mu \mathrm{A}$. The visualization and 3D renderings were performed using 3DSlicer software.

\section{Phylogenetic analysis}

The phylogenetic relationships of MACN$\mathrm{Pv}-\mathrm{N} 120$ within Squamata were tested using the phylogenetic dataset published by Gauthier et al. (2012) and subsequently modified by Simões et al. (2015a, b). MACN-Pv-N 120 was added to this data set, resulting in a data matrix composed of 610 morphological characters scored across 197 species-level terminals (Supporting Information). This matrix was analyzed with a fully unconstrained topology and alternatively using a constrained topology following a total evidence-based backbone (hereafter called unconstrained and constrained analysis/trees, respectively). The total evidence phylogenetic hypothesis follows that of Reeder et al. (2015: fig. 1 ), in which the extant major clades of Squamata have the following interrelationships: ((Gekkota + Dibamidae $)+($ Scincoidea + (Lacertoidea + (Serpentes + (Anguimorpha + (Pleurodonta + Acrodonta))) ))). We constrained the monophyly of each of these clades, as well as the interrelationships among them.

In both cases, the data matrix was analyzed under equally weighted parsimony using TNT 1.5 (Goloboff et al., 2008; Goloboff \& Catalano, 2016). The search strategies started using a combination of the tree-search algorithms Wagner trees, TBR branch swapping, sectorial searches, Ratchet and Tree Fusing, until 100 hits of the same minimum tree length were achieved. The best trees obtained were subjected to a final round of TBR branch swapping. This tree search strategy was designed to find the maximum number of most parsimonious trees (MPTs) spread across the widest possible swathe of tree space (see discussion in Langer et al., 2017), ensuring the finding of optimal topologies 100 times. By contrast, other heuristic tree search strategies using a determined number of replications may result in a considerably low number of hits of global optimal trees, not ensuring an optimal hit per replicate, and, thus, the risk of non-finding all possible MPTs. Zero length branches in any of the recovered most parsimonious trees were collapsed. The non-squamate lepidosaur Gephyrosaurus bridensis was used to root the trees and the following multistate characters 
were ordered (=additive) based on previous analyses (Simões et al., 2015b): 3, 7, 10, 12, 18, 25, 33, $38,39,41,43,45,48,49,51,56,58,63,65,66$, $67,70,80,82,83,84,90,93,97,99,101,102,105$, $106,108,111,114,120,126,128,129,130,132$, $133,140,141,143,149,152,155,167,168,178$, $182,184,185,187,188,189,203,204,208,216$, $217,220,223,231,238,242,248,250,251,256$, $258,260,263,268,271,276,277,283,285,288$, $300,301,302,303,306,309,311,312,316,326$, $328,337,340,343,346,347,349,350,360,361$, $364,368,369,372,375,382,388,389,390,392$, $394,396,414,415,418,419,420,421,435,440$, $454,455,456,457,458,459,460,463,468,475$, $477,483,486,487,488,518,529,535,570,572$, $584,588,589,590,593$, and 602 .

As a measure of branch support, decay indices (= Bremer support) were calculated (Bremer, 1994), and as a measure of branch stability, a bootstrap resampling analysis (Felsenstein, 1985) was conducted, performing 1,000 pseudoreplications. Both absolute and GC (i.e., difference between the frequency whereby the original group and the most frequent contradictory group are recovered in the pseudoreplications; Goloboff et al., 2003) bootstrap frequencies were reported. In order to analyze the effect that a few topologically unstable terminals may have on Bremer supports, this index was recalculated after the $a$ posteriori pruning of such terminals, which were previously detected in the subsample of suboptimal trees with the iterPCR protocol (Pol \& Escapa, 2009). Finally, analyses forcing topological constraints were conducted to find the minimum number of steps necessary to force alternative suboptimal positions for MACN-Pv-N 120.

\section{Institutional Abbreviations}

MACN-Pv-N, Museo Argentino de Ciencias Naturales 'Bernardino Rivadavia', Colección Paleovertebrados, Colección Neuquén, Buenos Aires, Argentina.

\section{RESULTS}

\section{Systematic Paleontology}

Reptilia Linnaeus, 1758 [Laurin \& Reisz, 2020] Diapsida Osborn, 1903 [Gauthier \& de Queiroz, 2020]

Lepidosauria Haeckel, 1866 [de Queiroz \& Gauthier, 2020a]

Squamata Oppel, 1811 [de Queiroz \& Gauthier, 2020b]

?Polyglyphanodontia Alifanov, 2000

\section{Paleochelco gen. nov.}

LSID. urn:lsid:zoobank.org:act:F8CC7556-90334DD8-93F3-08CB9B64F18

Etymology. "Paleo" in reference to old, antique, from the ancient Greek $\pi \alpha \lambda \alpha$ cós (palaiós), and "chelco", popular name used for lizards in some places of Central and South America.

Diagnosis. As for the type and only known species.

Type species. Paleochelco occultato.

\section{Paleochelco occultato sp. nov.}

(Figs. 2-6)

LSID. urn:lsid:zoobank.org:act:71A120B7-9B974427-AEF7-296817C9E9F5

Holotype. MACN-Pv-N 120, incomplete anterior half of skull that includes partial nasals, partial maxillae, prefrontals, frontals, vomers, left septomaxilla in transverse section, left lacrimal and anterior tip of jugal, and anterior portion of left palatine. The specimen was embedded in a sandstone block with abundant quartz clasts. The nasals and right maxilla are mostly preserved as natural molds (Figs. 2-6).

Type locality and horizon. Campus of the Universidad Nacional del Comahue, north of Neuquén City (Neuquén Province, Argentina), included within the series of outcrops that have been historically called "Boca del Sapo locality"; Bajo de la Carpa Formation (Río Colorado Subgroup; Neuquén Group, Neuquén Basin), Late Cretaceous, Santonian (Garrido, 2010).

Etymology. Occultato, from the Latin occultatum, meaning hidden, because the holotype remained unnoticed in the collections where it is housed for more than 35 years.

Diagnosis. Small lizard (estimated skull length between $2.0-2.5 \mathrm{~cm}$ ) that differs from other squamates on the basis of the following combination of character states: rostrum lacking ornamentation on the external surface of bones; lacrimal bone present; large anterodorsal process of prefrontal with a convex external surface; transversely wide vomer/palatine contact, forming an almost flat, ventrolaterally facing surface; anterior tip of jugal reaching the level of the maxillary tooth positions and fully exposed laterally below the orbit; broad and relatively long anteromedial process of palatine that runs along the lateral margin of the vomer; palatine with a small and pointed lateral process that articulates with the 

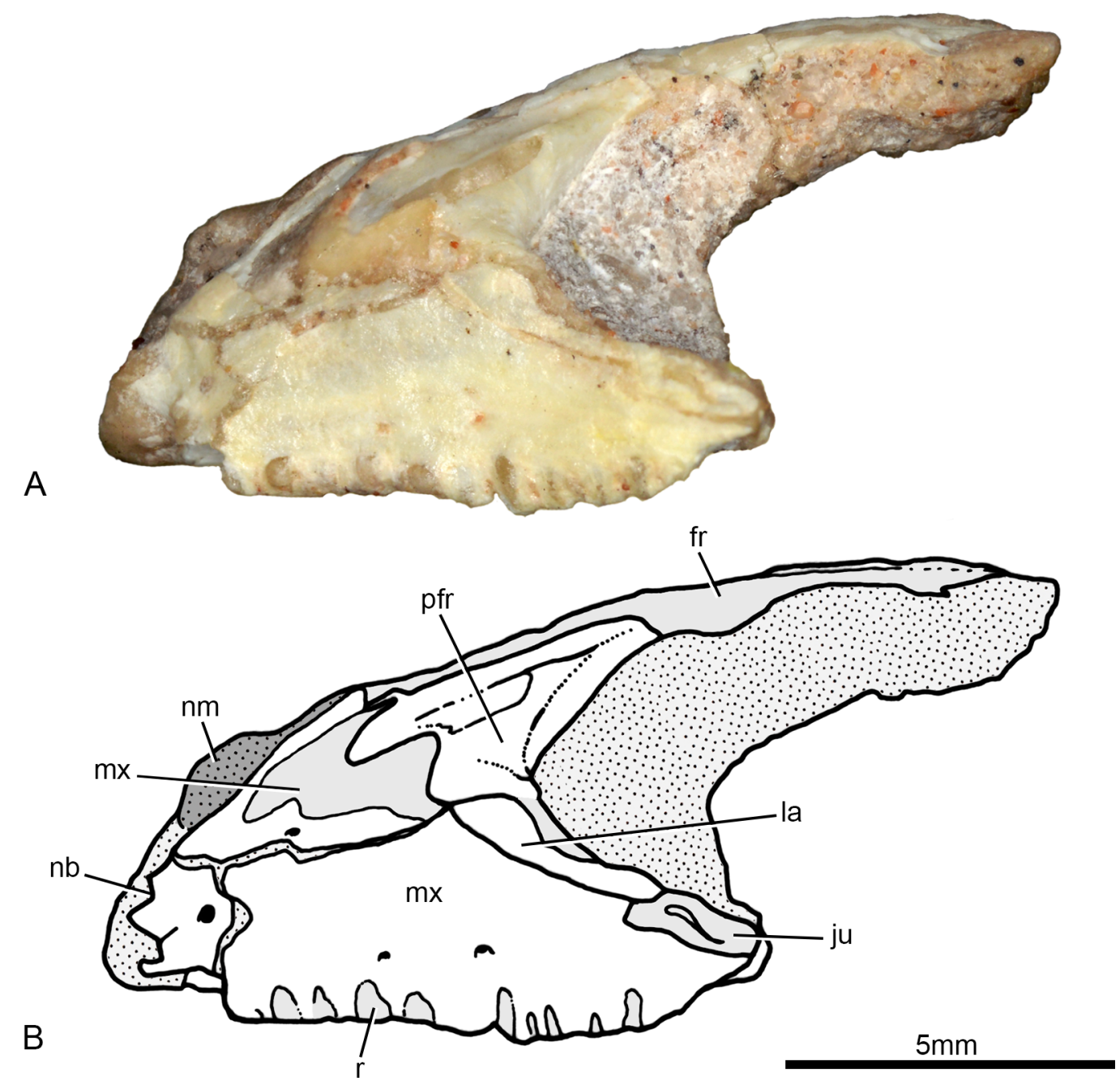

Fig. 2. Paleochelco occultato gen. et sp. nov. Holotype MACN-Pv-N 120. Partial skull in left lateral view (A) and accompanying drawing (B). Abbreviations: fr, frontal; ju, jugal; la, lacrimal; mx, maxilla; nb, narial border; nm, nasal mold; pfr, prefrontal; r, labially exposed root (due to weathering). Dotted surfaces indicate sedimentary matrix. Soft grey indicates bone surfaces partially eroded/broken.

maxilla; teeth with pleurodont implantation and absence of heavy deposits of cementum around the tooth bases.

\section{Description}

MACN-Pv-N 120 is represented by a damaged partial skull with generally weathered bone surfaces (Figs. 2-4). As a result of the latter, it is difficult to discern the limits between bones. The premaxillae are not preserved, thus the tip of the rostrum is unknown. However, the presence of the anterior region of the left maxilla, including part of the posterior edge of the external naris (Fig. 2), allows determining that the rostrum was relatively short anteroposteriorly, strongly tapering anteriorly, and probably shorter than the post-rostral region of the skull. The preserved external surface of the bones is smooth, lacking any sign of ornamentation.

Maxilla. The left maxilla is nearly complete, whereas the right one is strongly abraded, lacking the alveolar margin and all teeth. In lateral view, the maxilla is subtriangular in contour, with distinct anterior, dorsal, and posterior apices. The external surface of the bone is dorsoventrally convex and slightly anteroposteriorly concave on its ventral two-thirds (Fig. 2). The shape 


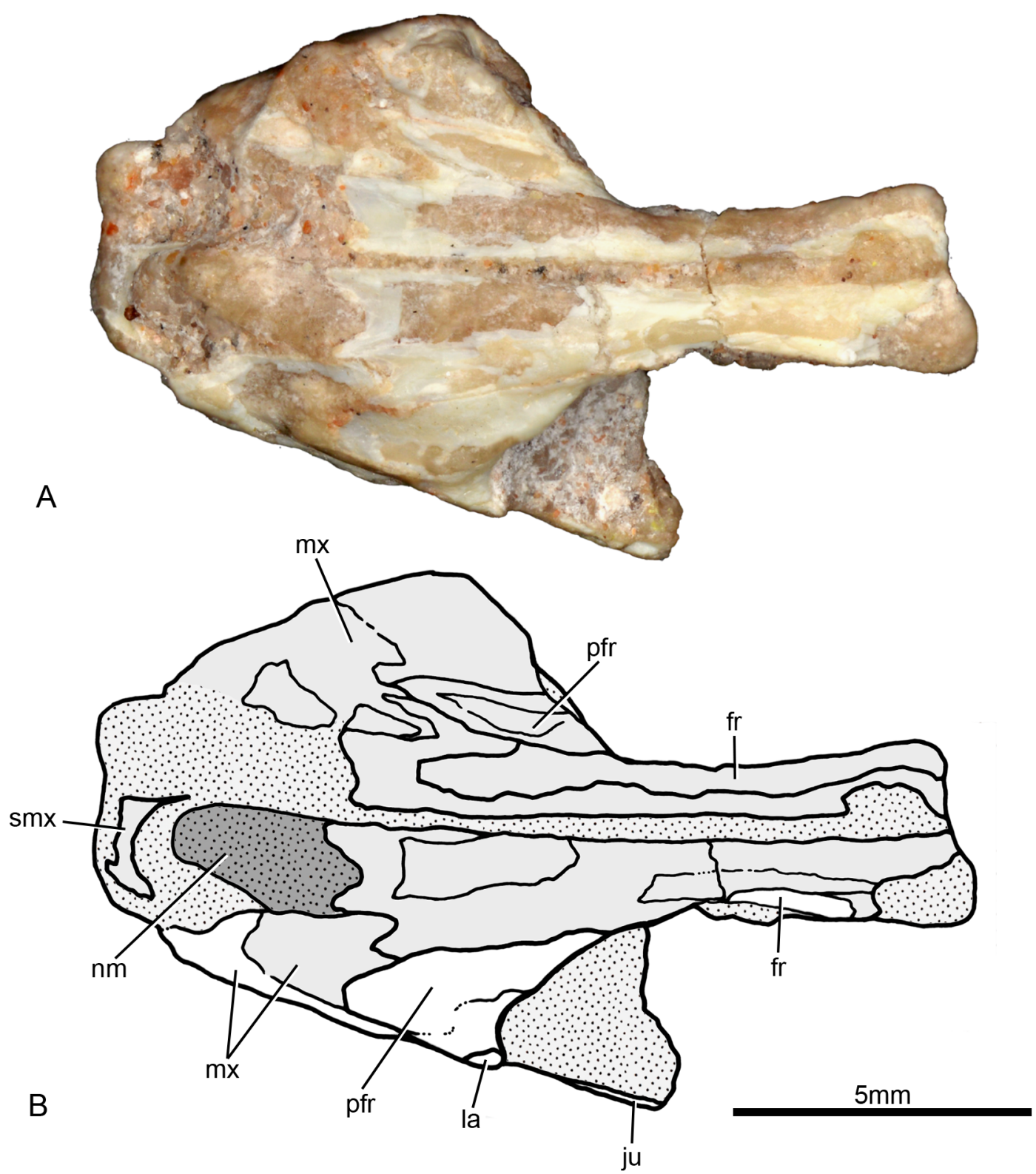

Fig. 3. Paleochelco occultato gen. et sp. nov. Holotype MACN-Pv-N 120. Partial skull in dorsal view (A) and accompanying drawing (B). Abbreviations: fr, frontal; ju, jugal; la, lacrimal; mx, maxilla; nm, nasal mold; pfr, prefrontal; smx, septomaxilla. Dotted surfaces indicate sedimentary matrix. Soft grey indicates bone surfaces partially eroded/broken.

of the maxilla results in a continuous transverse broadening of the rostrum towards the post-rostral region in dorsal and ventral views. The maxilla is dorsoventrally tall at its anterior half and strongly decreases in height posteriorly (Fig. 2). It is anteroposteriorly long, at least twice its maximum height. The anteroventral and posteroven- tral edges of the left maxilla are broken and, as a result, the exact tooth count is unknown, but at least 12 tooth positions are preserved. Small, subcircular foramina of sub-equal size open on the lateral surface of the maxilla approximately 0.9-1.00 $\mathrm{mm}$ dorsal to the alveolar margin of the bone and they are generally aligned to each alve- 


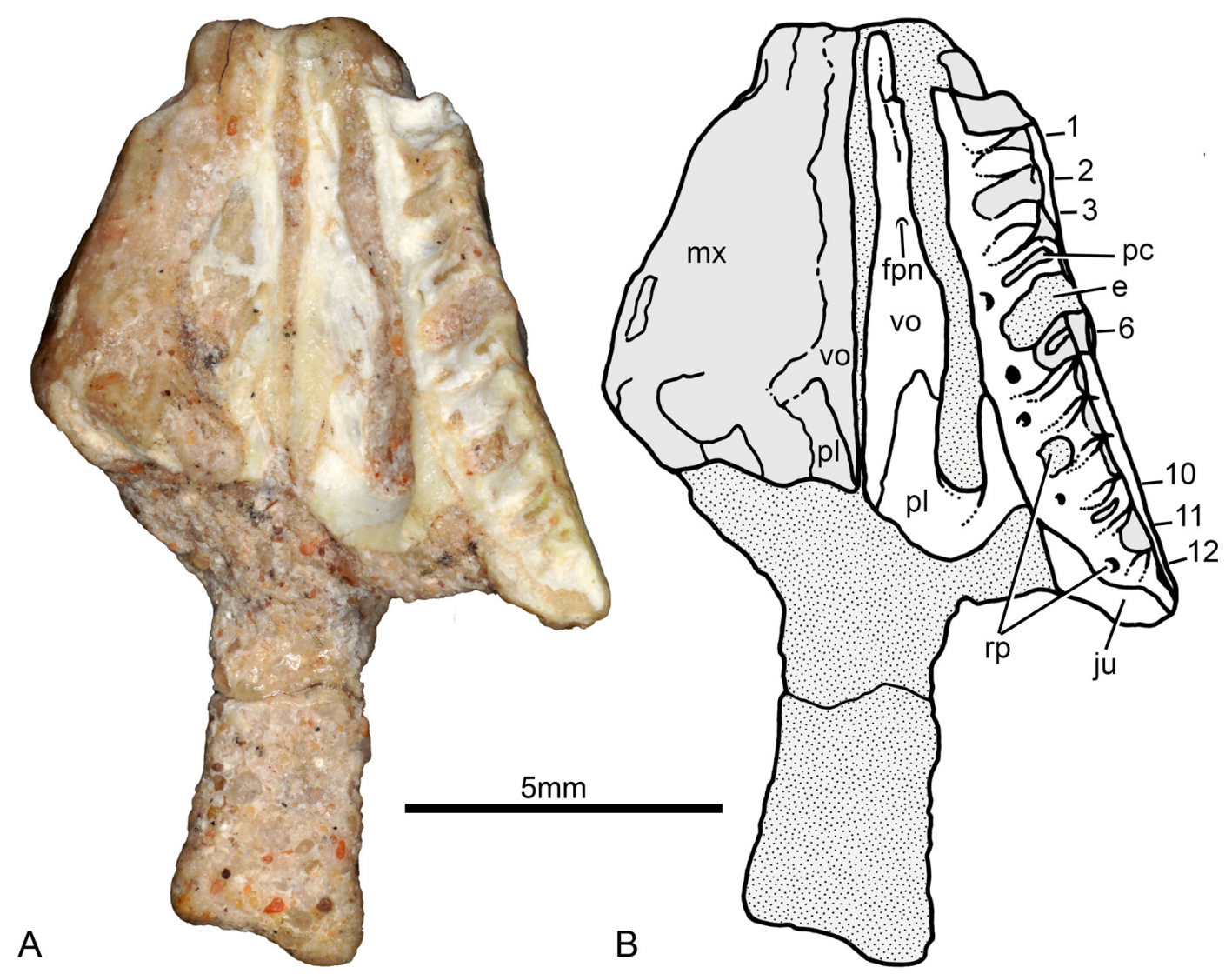

Fig. 4. Paleochelco occultato gen. et sp. nov. Holotype MACN-Pv-N 120. Partial skull in ventral view (A) and accompanying drawing (B). Abbreviations: 1-12, preserved tooth positions; e, empty alveolus; fpn, foramen for the medial palatine nerve; ju, jugal; mx, maxilla; pc, pulp cavity; pl, palatine; rp, replacement pit; vo, vomer. Dotted surfaces indicate sedimentary matrix. Soft grey indicates bone surfaces partially eroded/broken.

olus. There is a larger foramen positioned more anteriorly and dorsally than the others, matching the size and position of the anterior maxillary foramen present in several other saurians (e.g., Dilkes, 1998). The facial (= dorsal) process of the maxilla possesses a short contact with the frontal, anteriorly to the nasal-prefrontal suture (Figs. 2,3). The distal portion of the facial process bows medially and, as a result, its external surface faces dorsolaterally. The contact between the maxilla and the prefrontal is extensive, anterodorsally to posteroventrally oriented, and apparently slightly interdigitated. The suture with the lacrimal is longer than the latter, straight, and possesses a similar orientation, being inclined $\sim 30$ degrees from the coronal plane (Fig. 2). The anterior process of the maxilla is only partially preserved, but it is possible to recognize a small portion of a rounded, well-notched posteroventral border of the external narial opening. In left lateral view, part of the pulp cavity of the teeth is exposed because of the eroded surface of the alveolar margin (Fig. 2). The posterior process of the maxilla tapers posteriorly and extends distinctly beyond the level of the anterior border of the orbit. The medial surface of the maxilla is covered with matrix, but the contact with the palatine is exposed (Fig. 4). In ventral view, the maxilla forms a transversely narrow supradental shelf (=palatal shelf) (Fig. 6C). The $\mu \mathrm{CT}$ images show that the vertical thickness of the shelf is variable, tapering anteriorly and posteriorly, and relatively thick at the area where it contacts the palatine. Also, above the supradental shelf there is a longitudinal groove, which is interpreted as the superior alveolar canal (Fig. 6C).

Septomaxilla. A laminar bone is exposed in cross-section on the broken anterior region of the skull (Figs. 3, 5A). This bone is positioned 

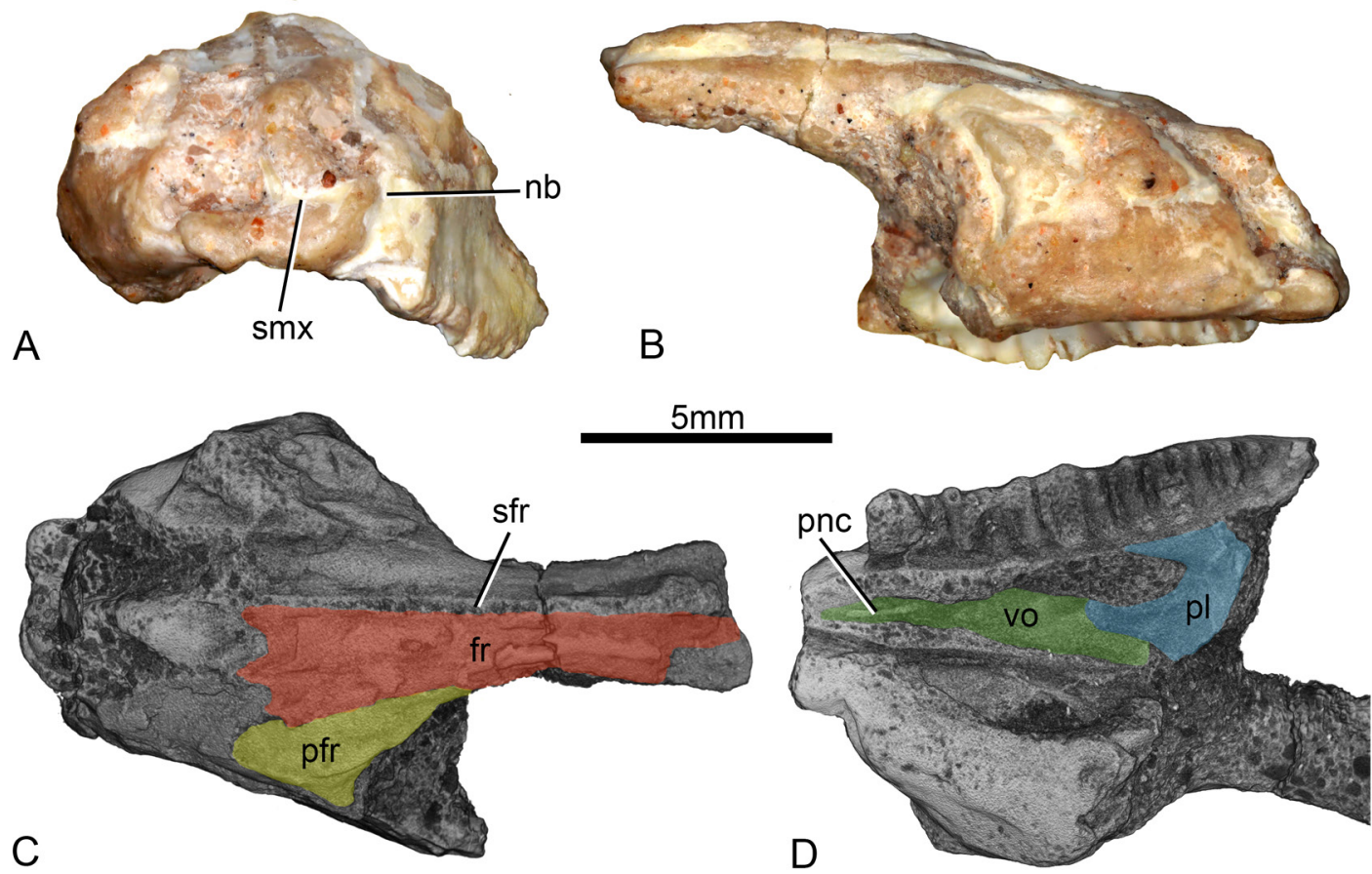

Fig. 5. Paleochelco occultato gen. et sp. nov. Holotype MACN-Pv-N 120. Partial skull in anterior (A) and right lateral (B) views. 3D rendering of the skull in dorsal view (C) and detail of the palate in posteroventral view (D). Abbreviations: fr, frontal; nb, narial border; pl, palatine; pfr, prefrontal; pnc, medial palatine nerve canal; sfr, suture between frontals; smx, septomaxilla; vo, vomer.

on the left half of the rostrum, dorsal to the vomers, and ventral to the mold of the nasals. As a result, it is interpreted as a partial left septomaxilla. The main portion of the septomaxilla is mainly transverse, with a slight ventromedial to dorsolateral orientation. This region is mostly straight (Fig. 5), contrasting with the strongly dorsally expanded and vaulted septomaxilla typical of scleroglossans. Thus, the shape of the septomaxilla indicates the presence of a relatively small vomeronasal organ in Paleochelco occultato, resembling the condition of iguanians and Cretaceous polyglyphanodontians (Gauthier et al., 2012). A short, dorsomedially oriented lamina indicates that the pair of septomaxillae formed a median partial septum. The morphology of the contact between the septomaxilla and other bones cannot be assessed either because of their damage or the region is covered with matrix.

Nasal. The nasals are poorly preserved. It cannot be determined whether they were paired or fused to each other (Fig. 3). The nasal is mostly eroded on the right side, whereas on the left side it is represented by a crystal mold. The nasal seems to have been considerably shorter than the frontal and has a posterior process with a rounded "V"-shaped edge that subdivided the anterior end of the frontal.

Lacrimal. The lacrimal is a splint-like and elongated bone with an anterodorsal to posteroventral orientation in lateral view (Fig. 2). This bone forms an extensive oblique suture with the maxilla and the external anteroventral border of the orbit. The orbital margin is not laterally raised. The dorsal tip of the lacrimal laterally overlaps the ventralmost region of the prefrontal. At this point, the suture defines a sharp process protruding to the orbital cavity (Fig. 2). The opening of the nasolacrimal duct is not preserved or exposed.

Jugal. Only the anteriormost tip of the anterior process of the left jugal is preserved (Figs. 2, 4). This small portion of the jugal indicates that this bone likely formed most of the ventral border of the orbit and its anterior tip reaches the level of the last three preserved maxillary tooth 
positions. The anterior process of the jugal overlaps laterally the posteriormost region of the lacrimal and is well exposed laterally ventral to the orbit, contrasting with the condition in sphenodonts and deeply nested polyglyphanodontians (Gauthier et al., 2012). In ventral view, the jugal also has a large contact with the maxilla, extending anteriorly up to the level of the tenth preserved tooth (Fig. 4).

Prefrontal. The prefrontal is a relatively large bone that forms most of the anterior border of the orbit (Figs. 2, 3, 5C). It is subtriangular in lateral view and has an anteroposteriorly and dorsoventrally convex external surface (Fig. 2). The prefrontal possesses a tongue-shaped anterior process that extensively contacts the maxilla ventrally and anteriorly, and the frontal dorsally. The quality of the $\mu \mathrm{CT}$ scan does not allow determining the degree of overlapping between the prefrontal and adjacent bones. The posterodorsal corner of the prefrontal possesses a small depression pierced by a tiny foramen. The posterodorsal region of the prefrontal tapers posteriorly and ends before the level of minimum width of the paired frontals, indicating that the latter bones participated on the external border of the orbit. There is a thin ventral process of the prefrontal that has an extensive anterodorsally to posteroventrally oriented suture with the lacrimal (Fig. 2). The posterior margin of the prefrontal is widely concave and does not raise laterally.

Frontal. The frontals are also poorly preserved, with most of their external surface eroded (Figs. $2,3)$. Nonetheless, they are clearly paired elements, with a longitudinal suture extended along their entire preserved length (Figs. 3, 5C). They are anteroposteriorly long bones and only slightly transversely constricted around the level of mid-length of the orbit, thus lacking a strong interorbital constriction or supraorbital shelf (Fig. 3). The frontal possesses an anteroposteriorly and a transversely convex external surface. Each frontal finishes anteriorly on a 'W'-shaped suture, with an anteromedial process that separates both nasals along the median line and a transversely broader anterolateral process that it is subdivided by the tapering dorsal process of the maxilla (Fig. 3). The ventral surface of the frontals is completely covered with matrix, but the $\mu \mathrm{CT}$ data shows that the olfactory tract is only incipiently laterally delimited, thus lacking subolfactory processes, and there is no median pillar. There is no evidence of a pineal foramen in the preserved region of the frontals, but this opening was probably present more posteriorly on the skull roof.

Vomer. The vomers are the most extensive elements in the preserved region of the palate (Fig. 4). These bones are paired and separated by a narrow longitudinal slit anteriorly and a median suture posteriorly. However, it cannot be ruled out that the apparent lack of contact between vomers on the anterior region of the palate is a result of taphonomic distortion. The anterior half of the vomer is relatively narrow and widens posteriorly, which results in a transversely narrow internal choana (Figs. 4, 5D). The area of the opening of the vomeronasal organ is covered with matrix, but the $\mu \mathrm{Ct}$ shows that the vomer contacted the palatal shelf of the maxilla. A small foramen, opened posteriorly, is placed at the level of the third preserved tooth, which is interpreted as the foramen for the medial palatine nerve (Figs. 4, 6A). The eroded anterior surface of the left vomer shows the anterior portion of the canal of the medial palatine nerve that is filled with matrix (Fig. 5D). The posterior end of the vomer possesses a V-shaped contact with the palatine, in which the apex is anteriorly oriented and laterally displaced from the level of mid-width of the hemipalate (Figs. 4, 5D). The right vomer is poorly preserved and the foramen for the medial palatine nerve seems to be more posteriorly placed than in the left side.

Palatine. The palatine is represented by the anterior portion of the left side element and a damage portion of the right one. It shows a relatively long and wide anteromedial process that forms an oblique, anterolaterally to posteromedially oriented, suture with the vomer (Fig. 4). The palatine possesses a small and pointed lateral process that articulates with the maxilla (Figs. 4, 5D). This lateral process has a well-developed anterior projection that results in a palatine-maxilla articulation that extends along the level of three tooth positions. Although incompletely preserved, a small posterolateral projection also exists. The lateral process of the palatine is separated from the medial one by a strongly concave margin that forms the posterior border of the internal choana. The ventral surface of the bone on the intersection between the lateral and anteromedial processes is distinctly depressed into a choanal fossa (Fig. 4B). Unfortunately, the degree of posterior extension of this fossa cannot be determined because of damage. 

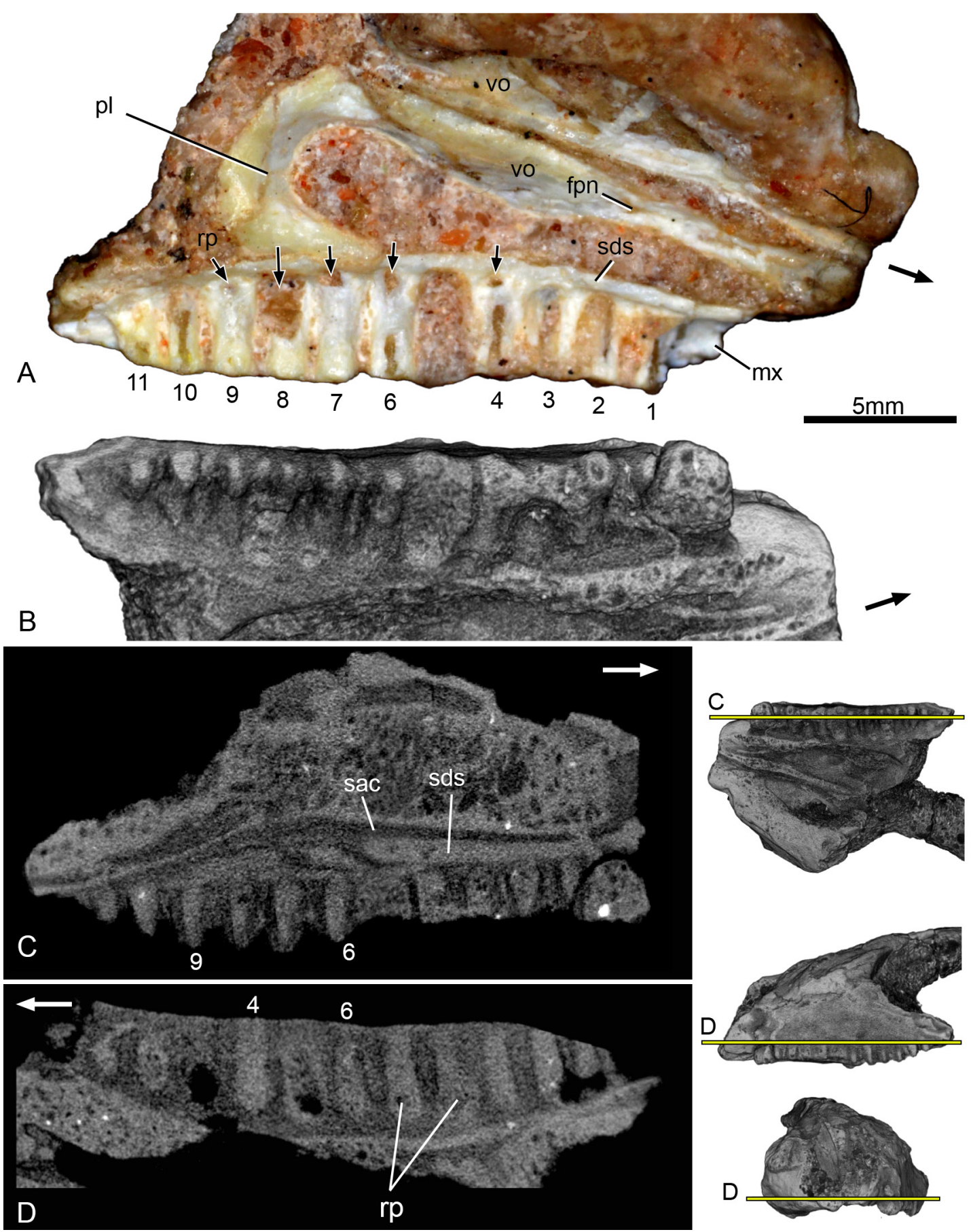

Fig. 6. Paleochelco occultato gen. et sp. nov. Holotype MACN-Pv-N 120. Detail of the left maxillary dentition in ventromedial view (A), positioning the tooth row in a vertical plane. 3D rendering of maxilla and dentition in ventral view (B). X-ray tomographic slices (C, D) of the left maxilla indicating the cutting planes in the images to the right. Abbreviations: 1-12, preserved tooth positions; fpn, foramen for the medial palatine nerve; $\mathrm{mx}$, maxilla; $\mathrm{pl}$, palatine; $\mathrm{rp}$, replacement pit (indicated by small arrows in A); sac, superior alveolar canal; sds, supradental shelf; vo, vomer. Arrows indicate anterior direction. 
Dentition. The dentition is partially preserved on the left maxilla, lacking the tips of all tooth crowns. The teeth have a pleurodont implantation and are ankylosed to the lingual side of the bone (Figs. 4, 6). No enamel is preserved and the pulp cavity is exposed in several teeth because of weathering (Figs. 2, 4, 6). The teeth increase in size distally until the ninth-tenth preserved position, and then decrease in size in the last two preserved teeth. The lingual side of each tooth is strongly apicobasally concave, with a labiolingually wide base about four times labiolingually broader than mesiodistally long (Fig. 6D). This part of the teeth is ankylosed to the maxillary bone. Each tooth is positioned close one to another, forming a fusiform notch in labiolingual view between successive teeth (Fig. 6). A replacement pit occurs at the base of some teeth on the lingual side, and they have different degrees of development (Fig. 6). These pits are clearly observed in the preserved third, fourth, sixth, seventh, eighth, ninth, and eleventh tooth positions, and the largest of them occurs in the eighth position. The preserved fifth tooth position is empty and lacks evidence of a functional tooth or a replacement. No further details can be provided about the tooth crown morphology. There is no evidence of palatal teeth in the preserved portions of vomers and palatines.

\section{Phylogenetic analysis}

Unconstrained analysis. The analysis found 10,032 most parsimonious trees (MPTs) of 5,306 steps with a consistency index (CI) of 0.18338 and a retention index (RI) of 0.79249 . The topology of the strict consensus tree is consistent to those found by Gauthier et al. (2012) and Simões et al. (2015a, b), but with a massive polytomy at the base of Iguania and unresolved relationships among the main clades of non-iguanian non"krypteian" squamates. The iterPCR protocol found that the Brazilian species Tijubina pontei and Olindalacerta brasiliensis are highly unstable taxa and their a posteriori pruning allowed recovering Polyglyphanodontia as the sister taxon to Scleroglossa + Mosasauria. The new taxon Paleochelco occultato is alternatively recovered at the base of Polyglyphanodontia, as the sister taxon to Polyglyphanodontia + Scleroglossa, or as one of the sister taxa to the Mosasauria + Scleroglossa clade (Fig. 7).

Constrained analysis. The phylogenetic analysis using the total evidence-based topological constrain found 19,008 MPTs of 5,464 steps with a consistency index (CI) of 0.17807 and a retention index (RI) of 0.78492 . The strict consensus tree is generally well resolved, but it has a massive polytomy composed of Lacertoidea, Polyglyphanodontia, Acrodonta, Anguimorpha, Pleurodonta, and Serpentes (Fig. 8). Paleochelco occultato is recovered within Polyglyphanodontia, in a trichotomy with Tchingisaurus multivagus and more deeply nested members of the clade. The iterPCR protocol found that the alternative positions of Olindalacerta brasiliensis as an anguimorph or an iguanian among the MPTs are the responsible of the massive polytomy. The strict reduced consensus tree with the $a$ posteriori pruning of Olindalacerta brasiliensis is well resolved. Tijubina pontei, which was one of the rogue species in the unconstrained analysis, is recovered in a trichotomy with Anguimorpha and the Polyglyphanodontia + Iguania clade (Fig. 8).

\section{Comparisons of Paleochelco occultato with main squamate clades}

Paleochelco occultato is easily distinguishable from Scincoidea, Lacertoidea, Anguimorpha, and Paramacellodidae by several features, including the absence of skull ornamentation and palpebral ossification (see Estes et al., 1988; Evans \& Chure, 1998; Conrad, 2008). Paleochelco occultato differs from iguanians by the absence of prefrontal tuberosity, strong medial process of maxilla, fused frontals that are constricted between orbits, and a frontal shelf (Estes et al., 1988; Gao \& Norell, 2000; Conrad \& Norell, 2007; Conrad, 2008). The new species differs from teioids and resembles polyglyphanodontians in having unfused frontals and lacking retracted external nares and maxillary sculpturing (Estes, 1983a; Denton \& O’Neill, 1995; Conrad, 2008). Paleochelco occultato also resembles polyglyphanodontians in lacking sculpturing on prefrontal,

Fig. 7. (Next page) Strict reduced consensus tree of the most parsimonious trees (MPTs) recovered in the unconstrained analysis showing the phylogenetic position of Paleochelco occultato gen. et sp. nov. among lizards. This analysis is based on the phylogenetic data set of Gauthier et al. (2012) and subsequent modifications by Simões et al. $(2015 \mathrm{a}, \mathrm{b})$. The alternative positions among the MPTs of the Early Cretaceous Brazilian lizards Tijubina pontei and Olindalacerta brasiliensis, which were pruned a posteriori from the consensus tree, are depicted using blue and red circles, respectively. Values below branches (from bottom/left to top/right) indicate Bremer support values, and absolute and GC (group present/contradicted) bootstrap frequencies. 


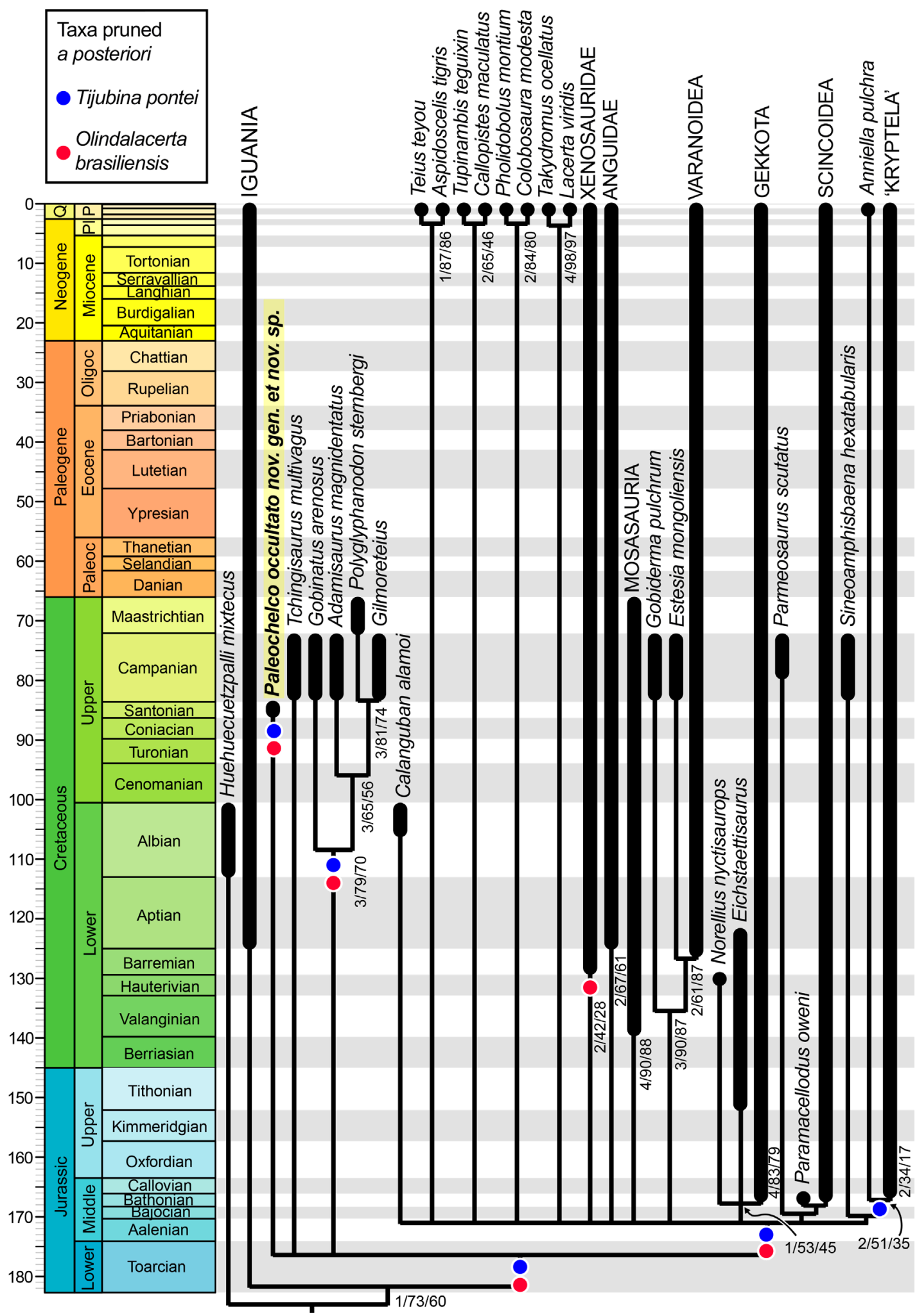


linear interorbital margins of frontals (Conrad, 2008), and maxillary tooth row beginning anterior to mid-orbit level (Gauthier et al., 2012). Thus, a phylogenetic placement of Paleochelco occultato close to or among polyglyphanodontians is also bolstered by these comparisons.

\section{DISCUSSION}

\section{The phylogenetic relationships of Paleochelco occultato}

Unconstrained analysis. Paleochelco occultato as a non-iguanian non-scleroglossan squamate is the best supported hypothesis, being recovered as an early Polyglyphanodontia, the sister taxon to Polyglyphanodontida + Scleroglossa, or as one of the sister taxa to the Scleroglossa + Mosasauria clade (Fig. 7). When Paleochelco occultato is recovered within Polyglyphanodontia, this taxon is found as its earliest branching species, the sister taxon to the Asian Tchingisaurus multivagus, or the sister taxon to all the other members of the clade (i.e., the Asiatic and North American Gobinatus arenosus, Adamisaurus magnidentatus, Polyglyphanodon sternbergi and Gilmoreteius). The placement of Paleochelco occultato within Polyglyphanodontia is supported by the presence of a frontal-maxilla suture, separating nasal from prefrontal (character 37: $0 \rightarrow 1$ ), and vomer extending backwards beyond anteriormost contact of palatine with maxilla (character 213: $0 \rightarrow 1$ ). The alternative positions of Paleochelco occultato and Tchingisaurus multivagus around the base of Polyglyphanodontia are not supported by apomorphies, but they are a result of the lack of overlapping phylogenetically informative characters between these two taxa for this part of the tree. Paleochelco occultato is excluded from more deeply nested polyglyphanodontians because of the absence of a jugal overlapping medially the lacrimal (character 145: $0 \rightarrow 1$ ) and a jugal failing to be laterally exposed below orbit (character 149: $2 \rightarrow 0$ ).

When Paleochelco occultato is found outside Polyglyphanodontia, its position as the sister taxon of the clade that includes polyglyphanodontians, mosasaurs and scleroglossans is supported by the presence of paired frontals (character 36: $1 \rightarrow 0$ ), contact between frontal and maxilla, separating nasal from prefrontal (character 37: $0 \rightarrow 1$ ), and septomaxilla with medial flange (character 205: $0 \rightarrow 1$ ). By contrast, the exclusion of Paleochelco occultato from the Polyglyphanodontia + Scleroglossa clade is not supported by any apomorphy. The placement of Paleochelco occultato closer to scleroglossans than to polyglyphanodontians is not supported by any apomorphy in our analysis, but its exclusion from the Mosasauria + Scleroglossa clade is a result of the absence of a septomaxilla dorsally expanded and convex, reflecting a large size of the vomeronasal organ (character 200: $0 \rightarrow 1$ ). In some other MPTs, the presence of a clade composed of Paleochelco accultato, Tijubina pontei (Early Cretaceous of Brazil), and (in some other trees) with Olindalacerta brasiliensis (Early Cretaceous of Brazil) is not supported by any apomorphy and the position of this South American clade as the sister taxon to the Mosasauria + Scleroglossa clade is based on the presence of an ectopterygoid with an obtuse angulation in dorsal view (character 272: $0 \rightarrow 1$ ) and ectopterygoid posterior process developed as a small lateral knob (character 283: $0 \rightarrow 1$ ) —but both character states are unknown in Paleochelco occultato-. In some MPTs, Paleochelco occultato is recovered closer to the Mosasauria + Scleroglossa clade than to Tijubina pontei and Olindalacerta brasiliensis, or alternatively the latter two taxa are closer to that clade. These positions are not supported by apomorphies in our analysis.

The branch supports around the alternative phylogenetic positions that Paleochelco occultato acquires among the MPTs are very low, with a minimum Bremer support and bootstrap frequencies below $20 \%$ for the clade that includes all squamates with the exception of iguanians. The a posteriori exclusion of Tijubina pontei and Olindalacerta brasiliensis, as suggested by the iterPCR protocol, slightly increases the resampling frequencies of this branch, but still $\leq 30 \%$. In this strict reduced consensus tree, the branch supports of Polyglyphanodontia, without Paleochelco occultato and Tchingisaurus multivagus, are high, with a Bremer support of 3 and bootstrap frequencies $\geq 70 \%$. By contrast, the

Fig. 8. (Next page) Strict reduced consensus tree of the most parsimonious trees (MPTs) recovered in the topologically constrained analysis (total-evidence backbone) showing the phylogenetic position of Paleochelco occultato gen. et sp. nov. among lizards. This analysis is based on the phylogenetic data set of Gauthier et al. (2012) and subsequent modifications by Simões et al. $(2015 \mathrm{a}, \mathrm{b})$. The alternative positions among the MPTs of the Early Cretaceous Brazilian lizard Olindalacerta brasiliensis, which were pruned a posteriori from the consensus tree, are depicted using red circles. Values below branches (from bottom/left to top/right) indicate Bremer support values, and absolute and GC (group present/contradicted) bootstrap frequencies. 


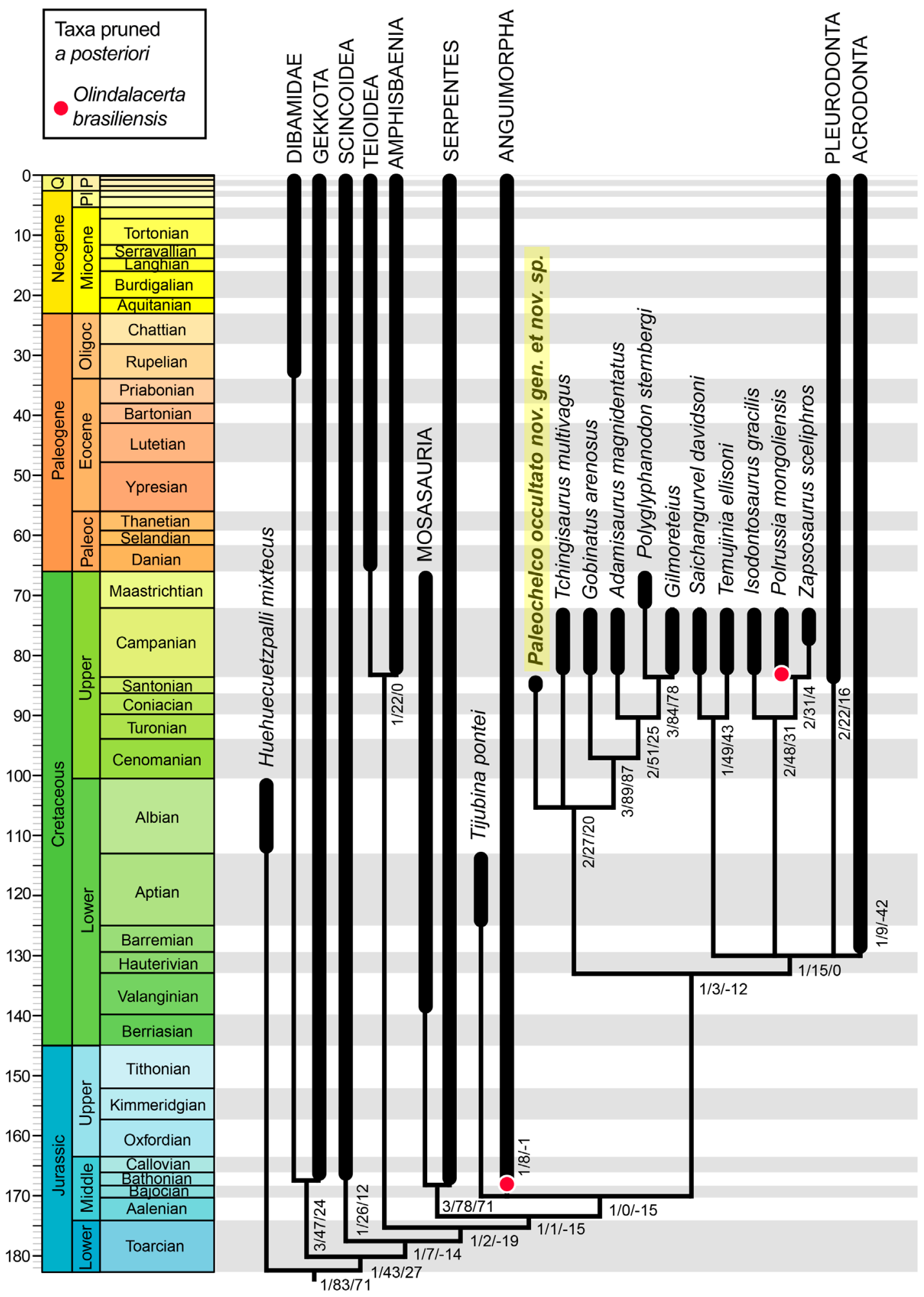


clade that includes mosasaurs and scleroglossans has very low branch supports.

Under constrained suboptimal topologies, three additional steps are necessary to place Paleochelco occultato at the base of Iguania (without synapomorphies supporting this hypothesis), one step to place it at the base of Mosasauria (supported by the absence of a nasal-prefrontal contact; character 19: $0 \rightarrow 1$ ), and two steps to be the sister taxon to or to be placed within Scleroglossa (without synapomorphies supporting the first hypothesis and the presence of a vomer extending backwards beyond anteriormost contact of palatine with maxilla as a synapomorphy of Paleochelco occultato + Autarchoglossa; character 213: $0 \rightarrow 1$ ). In particular, four extra steps are required to force a sister taxon relationship between Paleochelco occultato and the iguanian Gueragama sulamericana (mid-Cretaceous of Brazil) and five steps to find the new taxon as the sister species to Paramacellodus oweini (from the Jurassic-Cretaceous boundary of North America and Europe and very closely related to Neokotus sanfranciscanus from the late Early Cretaceous of Brazil). Both positions are not supported by synapomorphies, and it is very interesting to report that this constrain generates Gueragama sulamaricana to be positioned as a sister taxon to the Mosasauria + Scleroglossa clade, thus outside Iguania.

Constrained analysis. The position of Paleochelco occultato in this analysis is congruent with that in some of the unconstrained MPTs; i.e., as one of the earliest branching polyglyphanodontians (Fig. 8). The placement of Paleochelco occultato within Polyglyphanodontia and outside the clade composed of more deeply nested polyglyphanodontians is supported by the same synapomorphies as in the unconstrained analysis. After the a posteriori pruning of Olindalacerta brasiliensis, the calculated branch supports of Polyglyphanodontia, including Paleochelco occultato and Laurasian forms, are relatively low, with a Bremer support of 2 and bootstrap frequencies below $30 \%$. By contrast, the clade that includes polyglyphanodontians more deeply nested than Paleochelco occultato and Tchingisaurus multivagus is better supported, with a Bremer support of 3 and absolute and GC bootstrap frequencies of $89 \%$ and $87 \%$, respectively.

Under constrained suboptimal topologies (in addition to the original backbone), five additional steps are necessary to place Paleochelco occultato as a pleurodontan iguanian (supported by the presence of a maxillary facial process with a dorsolaterally facing apical surface, character 116: $0 \rightarrow 1$; and a frontal contacting maxilla, separating nasal from prefrontal, character $37: 0 \rightarrow 1$ ), six steps to place it as an acrodontan iguanian (without synapomorphies supporting this hypothesis), four steps to place it as an anguimorph or as the sister taxon to the clade composed of Mosasauria + Serpentes (without synapomorphies supporting these hypotheses), two steps to place it as a lacertoid (without synapomorphies supporting this hypothesis), three steps to place it as a gekkotan, closer to scincoidean than to other squamates, or as a paramacellodid (without synapomorphies supporting the first two hypotheses and the presence of a jugal entirely exposed laterally above orbital margin of maxilla, character 149: $0 / 1 \rightarrow 2$, supporting its placement as the sister taxon to the paramacellodid Parmeosaurus scutatus).

\section{Conclusions about the phylogenetic re- lationships of Paleochelco occultato. The} positions of Paleochelco occultato as a non-iguanian non-scleroglossan squamate in the unconstrained analysis and as a polyglyphanodontian in the constrained analysis are moderately well supported, respectively (Figs. 7-8). The affinities of Paleochelco occultato with polyglyphanodontians remain ambiguous in the unconstrained analysis, as well as the possible presence of a South American clade composed of the new taxon and the Brazilian Tijubina pontei and Olindalacerta brasiliensis. Both possible hypotheses have very interesting biogeographic implications. If the affinities of Paleochelco occultato with polyglyphanodontians are bolstered in the future, it would imply the presence of a Gondwanan representative of an otherwise Laurasian clade, as it has been previously suggested with the possible polyglyphanodontian affinities of the Brazilian Tijubina pontei and Olindalacerta brasiliensis (Simões et al., 2015a). Alternatively, if Paleochelco occultato, Tijubina pontei, and Olindalacerta brasiliensis form a clade to the exclusion of other squamates (only recovered in some MPTs of the unconstrained analysis), it would represent a South American or Gondwanan endemism of a Mesozoic squamate group with a completely unknown previous evolutionary history.

\section{Paleochelco occultato and its implications on the fossil record of lizards}

As indicated by previous authors (e.g., Evans, 
2003; Benson et al., 2013; Cleary et al., 2018), the main obstacle for understanding the early evolution and origins of different squamate lizard clades is probably the poorly documented fossil record in the Southern Hemisphere. Despite the paucity of this record, the growing fossil record of lepidosaurian taxa highlights a hidden history of the group in Gondwana (e.g., Bonaparte et al., 2010; Simões et al., 2015a, b; Bittencourt et al., 2020; Romo de Vivar et al., 2020).

Early to Middle Jurassic lizards are known from India (Evans et al., 2002) and a paramacellodid scincomorphan has been described from the Late Jurassic of Tanzania (Broschinski, 1999). The Early Cretaceous record of Gondwanan lizards is restricted to Brazil, with three different taxa of uncertain phylogenetic position, probably representing stem or early scleroglossans (Simões et al., 2015a, 2017). The Late Cretaceous fossil record of lizards in Gondwana counts with the occurrence of acrodontan iguanians in Africa (Apesteguía et al., 2016), scincoids in Madagascar (probably cordylids; Krause et al., 2003), and some remains from South America, including paramacellodids and acrodontan iguanians from Brazil (Simões et al., 2015b; Bittencourt et al., 2020). From the SantonianCampanian of Brazil, Nava \& Martinelli (2011) described Brasiliguana prudentis based on a maxilla as belonging to Iguania because of the weakly inclined anterior margin of the maxillary nasal process and the pleurodont tooth implantation. Further, Albino \& Brizuela (2014:351) mentioned that the maxilla of Brasiliguana prudentis does not present a strong/large palatine process, similar to the condition of Corytophaninae, Polychrotinae, Iguaninae, and Hoplocercinae. However, Brasiliguana prudentis shares with Polyglyphanodontidae the presence of waisted teeth with replacement pits at its base, and shares with chamopsiids a subpleurodont tooth attachment, a barrel-like tooth crown, and the subcircular cross-section of the teeth (Woolley et $a l ., 2020)$. Considering these features, non-iguanian affinities can be proposed for Brasiliguana prudentis. If affinities with chamopsiids are bolstered in the future (or with polyglyphanodontians considering their phylogenetic proximity), Brasiliguana prudentis and Paleochelco occultato could be nested among non-iguanian lizards, highlighting the diversity of still poorly known clades in the Late Cretaceous of South America.

Estes \& Price (1973) erected Pristiguana brasiliensis based on some cranial and postcranial remains from the Maastrichtian of Brazil.
They remarked features similar to teiioid lizards but interpreted them as plesiomorphies. Because of that, Borsuk-Białynicka \& Moody (1984; see also Benson et al., 2013) considered that the arguments for the iguanid assignment were not convincing and that Pristiguana brasiliensis could be assigned to the Teiidae. However, the combination of character states of Pristiguana brasiliensis sustains its iguanian affinities, as supported by other studies (e.g., Apesteguía et al., 2005; Nava \& Martinelli, 2011; Daza et al., 2012; Albino \& Brizuela, 2014; Martinelli \& Teixeira, 2015; Simões et al., 2017). In sum, the fossil record of Brazil is composed of early forms (scincomorphans or stem or very early scleroglossans), scincomorphs (paramacellodids), and both acrodontan and pleurodontan iguanians.

In contrast, the record of Cretaceous lizards in Argentina is restricted to a couple of poorly informative specimens. An isolated iguanian frontal was reported from the Cenomanian of Río Negro Province (Apesteguía et al., 2005). Daza et al. (2012) indicate that the character state combination listed by Apesteguía et al. (2005) is not exclusive to any lizard group. However, as sustained by Albino \& Brizuela (2014), the simultaneous presence of frontals with an hourglass-shaped contour determined by concave lateral margins, dermal sculpturing, transversely concave dorsal surface, and extensive supraorbital flanges are exclusively present in iguanians (see Apesteguía et al., 2005; Smith, 2009). In addition to this specimen, still unpublished remains from the same locality indicate that lizards were diverse and include not only iguanians, but probably other different clades (Apesteguía et al., 2019).

A poorly preserved dentary from the Campanian of northern Patagonia was referred to the Scincomorpha by Brizuela \& Albino (2011); they noted special affinities with scincoids. Together with the early paramacellodids from Brazil (Bittencourt et al., 2020), this dentary constitutes the only unambiguous scleroglossan (if it is actually a monophyletic clade) specimen from the Mesozoic of South America (Albino \& Brizuela, 2014). To this meager fossil record, we add the stem-scleroglossan or probably polyglyphanodontian (depending on the phylogenetic framework used) Paleochelco occultato.

Because squamates have a long fossil history that extends into the Triassic (Simões et al., 2018) and most of our knowledge of their early evolutionary history is derived from Laurasian records, several authors proposed that most 
lizard clades originated in the Northern Hemisphere and then arrived to South America during a possible biotic interchange with North America during the Campanian-Maastrichtian span (Borsuk-Białynicka \& Alifanov, 1991; Alifanov, 1993, 1994, 2016; Gao \& Hou, 1996). In this sense, the Cretaceous occurrence of polyglyphanodontians in North America (which were related to teiioids in morphological analyses; Estes, 1969, 1983b; Gao \& Fox, 1996; Gao \& Norell, 2000; Nydam et al., 2007) contributed to the hypothesis that South American teiioids were late surviving members of a Cretaceous teiioid migration from North into South America (Savage, 1966; Presch, 1974; Estes, 1983b; Estes \& Báez, 1985; Nydam et al., 2007; Giugliano et al., 2007). However, the alternative phylogenetic relationships of Paleochelco occultato, together with recent findings in other Cretaceous fossil sites from diverse Gondwanan landmasses, suggest that the early squamate faunas of the Southern Hemisphere were well integrated with faunas from other parts of the world. In this sense, phylogenetic data suggests that Toxicofera or Scleroglossa (depending on the phylogenetic hypothesis followed) separated before the breakup of Pangea, reinforcing the idea of an early radiation and wide distribution for most lizard clades (Simões, 2012; Bittencourt et al., 2020), as recently advocated for acrodontan iguanians (Simões et al., 2015b; Apesteguía et al., 2016). The recent findings of scincoids, acrodontans, pleurodontans, and stem scincomorphans also sustains that Gondwana was probably a major theater for the evolution of several lizard clades.

In contrast to a Mesozoic fossil record mainly composed of worldwide distributed taxa, the early Neogene to present squamate diversity in South America is characterized by taxa that are almost exclusive to that continent, including teiids, gymnophthalmids, tropidurids, liolaemids, leiosaurids, amphisbaenids, anomalepidids, and micrurids (e.g., Bittencourt et al., 2020). The absence of such clades in the Mesozoic record in the continent may be indicative of a post-Cretaceous explosive radiation and diversification that followed the mass extinction event (Longrich et al., 2012), as postulated for birds and mammals (e.g., Feduccia, 2003; O'Leary et al., 2013). Alternatively, this scenario would be the result of a still extremely poor Cretaceous squamate record in South America (see below).

Paleochelco occultato and the extinction of sphenodonts
Traditionally, the tuataras (Sphenodon punctatus) have been seen as a "living fossil" or relic of ancient times because sphenodonts had a highly diverse evolutionary history with an exquisite fossil record during the Mesozoic (e.g., Sues, 2019). However, the geographical range of sphenodonts seems to become restricted after the Middle Jurassic, first in Laurasia and later in Gondwana, being especially well-represented in Cretaceous beds of South America (Evans et al., 2001; Apesteguía \& Novas, 2003; Apesteguía, 2005; Jones, 2006; Apesteguía \& Rougier, 2007; Apesteguía \& Jones, 2012). This contraction was considered by some authors as the result of competition with squamate lizards (Carroll, 1988; Milner et al., 2000; Zug et al., 2001). Particularly for South America, it was proposed that the arrival of modern lizards coming from North America through Central America resulted in the competitive displacement of sphenodonts (Apesteguía \& Novas, 2003; Apesteguía \& Rougier, 2007; Apesteguía \& Jones, 2012). However, the discovery of "Laurasian advanced lizards" in South America since Early Cretaceous times (Simões, 2012; Nava \& Martinelli, 2011; Simões et al., 2015a,b, 2017; Bittencourt et al., 2020) indicates that sphenodonts and "modern" lizard clades coexisted for over 50 million years, thus making unlikely the "competitive displacement hypothesis" for explaining the disappearance of sphenodonts around the world. In this scheme, the presence of Paleochelco occultato in the Late Cretaceous of Patagonia reinforces the idea of Simões et al. (2015b) that sphenodontians were not necessarily dominant, at least in terms of taxonomic diversity, over squamates in South America as previously hypothesized. Perhaps the extremely poor Mesozoic lizard record in Gondwana is a result of biases in sampling because sphenodontians usually have more robust-built skulls, favoring its preservation in some fossil assemblages.

\section{ACKNOWLEDGEMENTS}

Our special gratitude to M. Lorena Cabirta and the staff of the Servicio de Microtomografía of the Facultad de Odontología, Universidad de Buenos Aires (Buenos Aires), for the scan of the holotype of Paleochelco occultato. We thank the authorities and conservation staff of the Museo Argentino de Ciencias Naturales "Bernardino Rivadavia" (Buenos Aires) for their continuous financial support and help in the conservation of the Colección Nacional de Paleovertebrados. We thank Lucas E. Fiorelli for discussions on the 
faunal composition at the different localities of the Bajo de la Carpa Formation. We thank the Editor Vanesa Arzamendia and the revisions of Tiago Simões and C. Agustín Scanferla, which improved the quality of the manuscript.

Supplementary Information. Phylogenetic data matrices in NEXUS and TNT formats available at http://morphobank.org/permalink/?P4059.

\section{BIBLIOGRAPHY}

Albino, A.M. 2002. El lagarto más antiguo de la Argentina. I Congreso 'Osvaldo A. Reig' de Vertebradología Básica y Evolutiva e Historia y Filosofía de la Ciencia, Buenos Aires, Resúmenes, p. 21.

Albino, A.M. 2007. Lepidosauromorpha. In: Z. Gasparini, R.A. Coria \& L. Salgado (eds.), Patagonian Mesozoic Reptiles, pp. 87-115, Indiana University Press, Bloomington, USA.

Albino, A.M. 2011. Evolution of Squamata reptiles in Patagonia based on the fossil record. Biological Journal of the Linnean Society 103: 441-457.

Albino, A.M. \& S. Brizuela. 2014. An overview of South American fossil squamates. The Anatomical Record 297: 349-368.

Alifanov, V.R. 1993. Some peculiarities of the Cretaceous and Palaeogene lizard faunas of the Mongolian People's Republic. Kaupia 3: 9-13.

Alifanov, V.R. 1994. The Upper Cretaceous lizard fauna from Mongolia and the problem of the first inter American contact. Paleontological Journal 27(3): 100-107.

Alifanov, V.R. 2000. Macrocephalosaurs and early stages of the evolution of lizards of Mongolia. Trudy Paleontologicheskogo Instituta Akademii Nauk SSSR 272: 1-126.

Alifanov, V.R. 2016. Lizards of the family Hodzhakuliidae (Scincomorpha) from the Lower Cretaceous of Mongolia. Paleontological Journal 50: 504-513.

Alvarenga, H.M.F. \& J.F. Bonaparte. 1992. A new flightless landbird from the Cretaceous of Patagonia. Natural History Museum of Los Angeles County, Science Series 36: 51-64.

Apesteguía, S. 2004. Bonitasaura salgadoi gen. et sp. nov.: a beaked sauropod from the Late Cretaceous of Patagonia. Naturwissenschaften 91: 493-497.

Apesteguía, S. 2005. A late Campanian sphenodontid (Reptilia, Diapsida) from northern Patagonia. Comptes Rendus Palevol 4: 663-669.

Apesteguía, S. \& M.E.H. Jones. 2012. A Late Cretaceous "tuatara" (Lepidosauria: Sphenodontinae) from South America. Cretaceous Research 34: 154-160.

Apesteguía, S. \& F.N. Novas. 2003. Large Cretaceous sphenodontian from Patagonia provides insight into lepidosaur evolution in Gondwana. Nature 425: 609-612.

Apesteguía, S. \& G.W. Rougier. 2007. A late Campanian sphenodontid maxilla from northern Patagonia. American Museum Novitates 3581: 1-11.

Apesteguía, S., F.L. Agnolin \& G. Lío. 2005. An early Late Cretaceous lizard from Patagonia, Argentina. Comptes Rendus Palevol 4: 311-315.

Apesteguía, S., J.D. Daza, T.R. Simões \& J.C. Rage. 2016. The first iguanian lizard from the Mesozoic of Africa. Royal Society Open Science 3: 160462.

Apesteguía, S., F.F. Garberoglio, R.O. Gómez, M.W. Caldwell, R.I. Nydam, T.R. Simões \& J. Kaluza. 2019. Lagartos de La Buitrera: una insospechada diversidad en el Cretácico Superior temprano de Argentina. XXXIII Jornadas Argentinas de Paleontología de Vertebrados, 2019, Córdoba, p. 7.

Benson, R.B.J., P.D. Mannion, R.J. Butler, P. Upchurch, A. Goswami \& S.E. Evans. 2013. Cretaceous tetrapod fossil record sampling and faunal turnover: Implications for biogeography and the rise of modern clades. Palaeogeography, Palaeoclimatology, Palaeoecology 372: 88-107.

Bittencourt, J.S., T.R. Simões, M.W. Cadwell \& M.C. Langer. 2020. Discovery of the oldest South American fossil lizard illustrates the cosmopolitanism of early South American squamates. Communications Biology 3:201.

Bonaparte, J.F. 1991. Los vertebrados fósiles de la Formación Río Colorado, de la ciudad de Neuquén y cercanías, Cretácico Superior, Argentina. Revista del Museo Argentino de Ciencias Naturales, Paleontología 4: 17-123.

Bonaparte, J.F, C.L. Schultz, M.B. Soares \& A.G. Martinelli. 2010. La Fauna Local de Faxinal do Soturno, Triásico Tardío de Rio Grande do Sul, Brasil. Revista Brasileira de Paleontologia 13(3): 1-14.

Bonfim-Júnior, F.C. \& R.B. Marques. 1997. Um novo lagarto do Cretáceo do Brasil (Lepidosauria, Squamata - Formação Santana, Aptiano da Bacia do Araripe). Anuário do Instituto de Geociências 20: 215-232.

Bonfim-Júnior, F.C. \& O. Rocha-Barbosa. 2006. A Paleoautoecologia de Tijubina pontei BonfimJúnior \& Marques, 1997 (Lepidosauria, Squamata basal da Formação Santana, Aptiano da Bacia do Araripe, Cretáceo Inferior do Nordeste do Brasil). Anuário do Instituto de Geociências 29: 54-65.

Borsuk-Białynicka, M. \& V.R. Alifanov. 1991. First Asiatic 'iguanid' lizards in the Late Cretaceous of Mongolia. Acta Palaeontologica Polonica 36(3): 325342.

Borsuk-Białynicka M. \& S.M. Moody. 1984. Priscagaminae, a new subfamily of the Agamidae (Sauria) from the Late Cretaceous of the Gobi Desert. Acta Palaeontogica Polonica 29: 51-81.

Bremer, K. 1994. Branch support and tree stability. Cladistics 10: 295-304.

Brissón Egli, F., F.L. Agnolin \& F. Novas. 2016. A new specimen of Velocisaurus unicus (Theropoda, Abelisauroidea) from the Paso Córdoba locality (Santonian), Río Negro, Argentina. Journal of Vertebrate Paleontology 36(4): e1119156.

Brizuela, S. \& A.M. Albino. 2011. A scincomorph liz- 
ard from the Campanian of Patagonia. Cretaceous Research 32: 781-785.

Broschinski, A. 1999. Ein Lacertilier (Scincomorpha, Paramacellodidae) aus dem Oberen Jura von Tendaguru (Tansania). Fossil Record 2: 155-158.

Broschinski, A. \& D. Sigogneau-Russell. 1996. Remarkable lizard remains from the Lower Cretaceous of Anoual (Morocco). Annales de Paléontologie (Vert.-Invert.) 82: 147-175.

Calvo, J.O. \& B.J. González Riga. 2003. Rinconsaurus caudamirus gen. et sp. nov., a new titanosaurid (Dinosauria, Sauropoda) from the Late Cretaceous of Patagonia, Argentina. Revista Geológica de Chile 30(2): 333-353.

Calvo, J., S. Engelland, S. Heredia \& L. Salgado. 1997. First record of dinosaur eggshell (Sauropoda-Megaloolithidae) from Neuquén, Patagonia, Argentina. GAIA 14: 23-32.

Candeiro, C.R., W. Nava, A.G. Martinelli, A.M. Forasiepi, C.A. Scanferla \& P. Muzzopappa. 2009. New lizard record (Diapsida; Lepidosauria) from the Late Cretaceous Adamantina Formation, Brazil. Bulletin of Geosciences 84: 573-576.

Carroll, R.L. 1988. Vertebrate Paleontology and Evolution. Freeman, New York, 698 pp.

Chiappe, L.M. \& J.O. Calvo. 1994. Neuquenornis volans, a new Late Cretaceous bird (Enantiornithes: Avisauridae) from Patagonia, Argentina. Journal of Vertebrate Paleontology 14(2): 230-246.

Cleary, T.J., R.B.J. Benson, S.E. Evans \& P.M. Barrett. 2018. Lepidosaurian diversity in the Mesozoic-Palaeogene: the potential roles of sampling biases and environmental drivers. Royal Society Open Science 5(3): 171830

Conrad, J.L. 2008. Phylogeny and systematic of Squamata (Reptilia) based on morphology. Bulletin of the American Museum of Natural History 310: 1-182.

Conrad, J.L. \& M.A. Norell. 2007. A complete Late Cretaceous iguanian (Squamata, Reptilia) from the Gobi and identification of a new iguanian clade. American Museum Novitates 3584: 1-47.

Coria, R.A., F. Ortega, A.B. Arcucci \& P.J. Currie. 2019. A new and complete peirosaurid (Crocodyliformes, Notosuchia) from Sierra Barrosa (Santonian, Upper Cretaceous) of the Neuquén Basin, Argentina. Cretaceous Research 95: 89-105.

Coria, R.A., L.S. Filippi, L.M. Chiappe, R.A. García \& A.B. Arcucci. 2013. Overosaurus paradasorum gen. et sp. nov., a new sauropod dinosaur (Titanosauria: Lithostrotia) from the Late Cretaceous of Neuquén, Patagonia, Argentina. Zootaxa 3683: 357-376.

Cruzado-Caballero, P., A.H. Méndez, L.S. Filippi, R.D. Juárez Valieri \& A.C. Garrido. 2016. Paleobiodiversity of the Bajo de la Carpa Formation (Santonian, Upper Cretaceous) in the Cerro OveroLa Invernada area, northern Patagonia, Argentina. VII Jornadas Internacionales sobre Paleontología de Dinosaurios y su Entorno. Sala de los Infantes, Burgos, España, pp. 53.

Cruzado-Caballero, P., J.M. Gasca, L.S. Filippi, I. Cerda \& A.C. Garrido. 2019. A new ornithopod dinosaur from the Santonian of Northern Patagonia (Rincón de los Sauces, Argentina). Cretaceous Research 98: 211-229.

Daza, J.D., V. Abdala, J.S. Arias, D. Garcı-López \& P. Ortiz. 2012. Cladistic analysis of Iguania and a fossil lizard from the late Pliocene of northwestern Argentina. Journal of Herpetology 46: 104-119.

DeMar Jr, D.G., J.L. Conrad, J.J. Head, D.J. Varricchio \& G.P. Wilson. 2017. A new Late Cretaceous iguanomorph from North America and the origin of New World Pleurodonta (Squamata, Iguania). Proceedings of the Royal Society B 284: 20161902.

Denton, R. \& R. O'Neill. 1995. Prototeius stageri, gen. et sp. nov., a new teiid lizard from the Upper Cretaceous Marshalltown Formation of New Jersey, with a preliminary phylogenetic revision of the Teiidae. Journal of Vertebrate Paleontology 15: 235253.

de Queiroz, K. \& J.A. Gauthier. 2020a. Lepidosauria. In: K. de Queiroz, P.D. Cantino \& J.A. Gauthier (eds.), Phylonyms - A Companion to the PhyloCode, pp. 1079-1085, CRC Press: Boca Raton.

de Queiroz, K. \& J.A. Gauthier. 2020b. Squamata. In: K. de Queiroz, P.D. Cantino \& J.A. Gauthier (eds.), Phylonyms - A Companion to the PhyloCode, pp. 1093-1101, CRC Press: Boca Raton

Dilkes, D.W. 1998. The Early Triassic rhynchosaur Mesosuchus browni and the interrelationships of basal archosauromorph reptiles. Philosophical Transactions of the Royal Society of London B 353: 501-541.

Estes, R. 1969. Relationships of two Cretaceous lizards (Sauria, Teiidae). Breviora 317: 1-8.

Estes, R. 1983a. Sauria terrestria, Amphisbaenia. In: P. Wellnhofer (ed.), Handbuch der Paläoherpetologie, 10A, Gustav Fischer Verlag, Stuttgart, Germany, $249 \mathrm{pp}$.

Estes, R. 1983b. The fossil record and the early distribution of lizards. In: A.G.J. Rhodin \& K. Miyata (eds.), Advances in Herpetology and Evolutionary Biology: Essays in Honor of E. E. Williams, pp. 365-398 Museum of Comparative Zoology, Harvard University, Cambridge, Massachusetts.

Estes, R. \& A.M. Báez. 1985. Herpetofaunas of North and South America during the Late Cretaceous and Cenozoic: evidence for interchange? In: F.G. Stehli \& S.D. Webb (eds.), The Great American Biotic Interchange, pp. 139-195, Plenum Press, New York, USA.

Estes, R. \& L.I. Price. 1973. Iguanid lizard from the Upper Cretaceous of Brazil. Science 180: 748-751.

Estes, R., K. de Queiroz \& J. Gauthier. 1988. Phylogenetic relationships within Squamata. In: R. Estes \& G. Pregill (eds.), Phylogenetic Relationships of the Lizard Families. Essays commemorating Charles L. Camp, pp. 119-281, Stanford University Press, California, USA.

Evans, S.E. 2003. At the feet of the dinosaurs: the early history and radiation of lizards. Biological Reviews 78: 513-551.

Evans, S.E. \& D.C. Chure, 1998. Paramacellodid lizard skulls from the Jurassic Morrison Formation 
at Dinosaur National Monument, Utah. Journal of Vertebrate Paleontology 18: 99-114.

Evans, S.E. \& M.E.H. Jones. 2010. The origin, early history and diversification of lepidosauromorph reptiles. In: S. Bandyopadhyay (ed.), New Aspects of Mesozoic Biodiversity, pp. 27-44. Lecture Notes in Earth Sciences, Springer.

Evans, S.E., G.V.R. Prasad \& B.K. Manhas. 2001. Rhynchocephalians (Diapsida: Lepidosauria) from the Jurassic Kota Formation of India. Zoological Journal of the Linnean Society 133: 309-334.

Evans, S.E., G.V.R. Prasad \& B.K. Manhas. 2002. Fossil lizards from the Jurassic Kota Formation of India. Journal of Vertebrate Paleontology 22(2): 299-312.

Evans, S.E. \& Y. Wang. 2010. A new lizard (Reptilia: Squamata) with exquisite preservation of soft tissue from the Lower Cretaceous of Inner Mongolia, China. Journal of Systematic Palaeontology 8: 8195.

Evans, S.E. \& Y. Yabumoto. 1998. A lizard from the Early Cretaceous Crato Formation, Araripe Basin, Brazil. Jahrbuch für Geologie und Paläontologie, Monatshefte 6: 349-364.

Ezcurra, M.D. \& A.H. Méndez. 2009. First report of a derived abelisaurid theropod from the Bajo de la Carpa Formation (Late Cretaceous), Patagonia, Argentina. Bulletin of Geosciences 84: 547-554.

Feduccia, A. 2003. 'Big bang' for tertiary birds? Trends in Ecology \& Evolution 18(4): 172-176.

Felsenstein, J. 1985. Phylogenies and the comparative method. The American Naturalist 125(1): 1-15.

Filippi, L.S., A.G. Martinelli \& A.C. Garrido. 2015. Una nueva asociación de dientes de vertebrados para la Formación Bajo de la Carpa (Santoniense, Cretácico Superior) en Rincón de los Sauces, Neuquén, Argentina. Spanish Journal of Palaeontology 30: 223-238.

Fillippi, L.S., F. Barrios \& A.C. Garrido. 2018. A new peirosaurid from the Bajo de la Carpa Formation (Upper Cretaceous, Santonian) of Cerro Overo, Neuquén, Argentina. Cretaceous Research 83: 7583.

Filippi, L.S., A.H. Méndez, R.F. Juárez Valieri \& A.C. Garrido. 2016. A new brachyrostran with hypertrophied axial structures reveals an unexpected radiation of latest Cretaceous abelisaurids. Cretaceous Research 61: 209-219.

Fiorelli, L.E. 2010. Predation bite-marks on a peirosaurid crocodyliform from the Upper Cretaceous of Neuquén Province, Argentina. Ameghiniana 47(3): 387-400.

Fiorelli, L.E. \& J.O. Calvo. 2007. The first "protosuchian" (Archosauria: Crocodyliformes) from the Cretaceous (Santonian) of Gondwana. Arquivos do Museu Nacional, Rio de Janeiro 65: 417-459.

Gao, K.-Q \& R.C. Fox. 1996. Taxonomy and evolution of Late Cretaceous lizards (Reptilia: Squamata) from western Canada. Bulletin of the Carnegie Museum of Natural History 33: 1-107.

Gao, K.-Q \& L. Hou. 1996. Iguanians from the Upper Cretaceous Djadochta Formation, Gobi Desert, China. Journal of Vertebrate Paleontology 15: 57-78.
Gao, K.-Q \& M.A. Norell. 1998. Taxonomic revision of Carusia intermedia (Reptilia: Squamata) from the Upper Cretaceous of Gobi Desert and phylogenetic relationships of anguimorphan lizards. American Museum Novitates 3230: 1-51.

Gao, K.-Q \& M.A. Norell. 2000. Taxonomic composition and systematics of Late Cretaceous lizard assemblages from Ukhaa Tolgod and adjacent localities, Mongolian Gobi desert. Bulletin of the American Museum of Natural History 249: 1-118.

Garrido, A.C. 2010. Estratigrafía del Grupo Neuquén, Cretácico Superior de la Cuenca Neuquina (Argentina): nueva propuesta de ordenamiento litoestratigráfico. Revista del Museo Argentino de Ciencias Naturales, n.s. 12(2): 121-177.

Garrido, A.C. \& J.O. Calvo. 2004. Reasignación litoestratigráfica de los niveles portadores de Megaloolithus patagonicus Calvo et al. (Dinosauria: Sauropoda) en las bardas de la ciudad de Neuquén. Ameghiniana (Suplemento) 41(4): 47R.

Gasparini, Z.B. de. 1971. Los Notosuchia del Cretácico da América del Sur como un nuevo Infraorden de los Mesosuchia (Crocodilia). Ameghiniana 8(2): 83-103.

Gauthier, J., R. Estes \& K. de Queiroz. 1998. A phylogenetic analysis of Lepidosauromorpha. In: R. Estes \& G. Pregill (eds.), Phylogenetic Relationships of the Lizard Families. Essays Commemorating Charles L. Camp, pp. 15-98, Stanford University Press, California, USA.

Gauthier, J.A. \& K. de Queiroz. 2020. Lepidosauria. In: K. de Queiroz, P.D. Cantino \& J.A. Gauthier (eds.), Phylonyms - A Companion to the PhyloCode, pp. 1033-1040, CRC Press: Boca Raton.

Gauthier, J.A., M. Kearney, J.A. Maisano, O. Rieppel \& A.D.B Behlke. 2012. Assembling the squamate tree of life: perspectives from the phenotype and the fossil record. Bulletin of the Yale Peabody Museum 53: 3-308.

Gianechini, F.A, A.H. Méndez, L.S. Filippi, A. PaulinaCarabajal, R.D. Juárez-Valieri \& A.C. Garrido. 2021. A new furileusaurian abelisaurid from La Invernada (Upper Cretaceous, Santonian, Bajo de la Carpa Formation), northern Patagonia, Argentina. Journal of Vertebrate Paleontology 40(6): e1877151.

Giugliano, L.G., R. Garcia Collevatti \& G.R. Colli. 2007. Molecular dating and phylogenetic relationships among Teiidae (Squamata) inferred by molecular and morphological data. Molecular Phylogenetics and Evolution 45: 168-179.

Goloboff, P.A. \& S.A. Catalano. 2016. TNT version 1.5, including a full implementation of phylogenetic morphometrics. Cladistics 32: 221-238.

Goloboff, P.A., J.S. Farris \& K.C. Nixon. 2008 TNT, a free program for phylogenetic analysis. Cladistics 24: 774-786.

Goloboff, P.A., J.S. Farris, M. Källersjö, B. Oxelman, M. Ramírez \& C. Szumik. 2003. Improvements to resampling measures of group support. Cladistics 1: 324-332.

Haeckel, E. 1866. Generelle Morphologie der Organismen. Band 2: Allgemeine Entwicklungsgeschichte der Organismen. George 
Reimer, Berlin.

Herrera-Flores, J.A., T.L. Stubbs \& M.J. Benton. 2021. Ecomorphological diversification of squamates in the Cretaceous. Royal Society Open Science 8: 201961.

Hugo, C.A. \& H.A. Leanza. 2001. Hoja Geológica 3069IV General Roca (escala 1:250.000). Provincias de Río Negro y Neuquén. Instituto de Geología y Recursos Minerales. SEGEMAR. Boletín 308: 1-65. Buenos Aires.

Jiménez-Gomis, C., P. Cruzado-Caballero, J.M. Gasca \& L.S. Filippi. 2018. New fossils of ornithopod dinosaurs from the Santonian (Upper Cretaceous) of the Bajo de la Carpa Formation of North Patagonia (Neuquén, Argentina). Geogaceta 64: 83-86.

Jones, M.E.H. 2006. The Early Jurassic clevosaurs from China (Diapsida: Lepidosauria). In: J.D., Harris, S. Lucas, J. Kirkland \& A.R.C. Milner (eds), The Triassic/Jurassic Terrestrial Transition, pp. 548-562, New Mexico Museum of Natural History and Science Bulletin, 37, Albuquerque, New Mexico, USA.

Juárez Valieri, R.D. \& J.O. Calvo. 2011. Revision of MUCPv 204, a Senomanian basal titanosaur from Northern Patagonia. In: J. Calvo, J. Porfiri, B. González Riga \& D. Dos Santos (eds.), Dinosaurios y Paleontología desde América Latina, pp. 143152. Anales del III Congreso Latinoamericano de Paleontología, Neuquén, 2008, Editorial de la Universidad Nacional de Cuyo, Mendoza.

Krause, D.W., S.E. Evans \& K.-Q Gao. 2003. First definitive record of Mesozoic lizards from Madagascar. Journal of Vertebrate Paleontology 23(4): 842-856.

Langer, M.C., M.D. Ezcurra, O.W.M. Rauhut, M.J. Benton, F. Knoll, B. McPhee, F.E. Novas, D. Pol \& S.L. Brusatte. 2017. Untangling the dinosaur family tree. Nature 551: E1-E3.

Lapparent de Broin, F. de \& M.S. de la Fuente. 2001. Oldest world Chelidae (Chelonii, Pleurodira), from the Cretaceous of Patagonia. Comptes Rendues Académie des Sciences de Paris 333: 463-470.

Laurin, M. \& R.R. Reisz. 2020. Reptilia. In: K. de Queiroz, P.D. Cantino \& J.A. Gauthier (eds.), Phylonyms - A Companion to the PhyloCode, pp. 1027-1031, CRC Press: Boca Raton.

Leardi, J.M., L.E. Fiorelli \& Z. Gasparini. 2015. Redescription and reevaluation of the taxonomical status of Microsuchus schilleri (Crocodyliformes: Mesoeucrocodylia) from the Upper Cretaceous of Neuquén, Argentina. Cretaceous Research 52: 153166.

Leardi, J.M., D. Pol \& Z. Gasparini. 2018. New Patagonian baurusuchids (Crocodylomorpha; Notosuchia) from the Bajo de la Carpa Formation (Upper Cretaceous; Neuquén, Argentina): New evidences of the early sebecosuchian diversification in Gondwana. Comptes Rendus Palevol 17(8): 504-521.

Leanza, H.A. \& C.A. Hugo. 1997. Hoja Geológica 3969III- Picún Leufú, provincias del Neuquén y Río Negro. Instituto de Geología y Recursos Naturales. SEGEMAR. Boletín 218: 1-135. Buenos Aires.

Leanza, H.A. \& C.A. Hugo. 2001. Hoja Geológica $3969-$
I - Zapala, provincia del Neuquén. Instituto de Geología y Recursos Naturales. SEGEMAR. Boletín 275: 1-128. Buenos Aires.

Leanza, H.A., S. Apesteguía, F.E Novas, M.S. de la Fuente. 2004. Cretaceous terrestrial beds from the Neuquén Basin (Argentina) and their tetrapod assemblages. Cretaceous Research 25: 61-87.

Linnaeus, C.v. 1758. Systema naturae per regna tria naturae: secundum classes, ordines, genera, species, cum characteribus, differentiis, synonymis, locis. Holmiae, Impensis Direct. Laurentii Salvii, 17581759.

Lio, G., F.L. Agnolin, A.G. Martinelli, M.D. Ezcurra \& F.E. Novas. 2018. New specimen of the enigmatic, Late Cretaceous crocodyliform Neuquensuchus universitas sheds light on the anatomy of the species. Cretaceous Research 83: 62-74.

Longrich, N.R., B.-A.S. Bhullar \& J.A. Gauthier. 2012. Mass extinction of lizards and snakes at the Cretaceous-Paleogene boundary. Proceedings of the National Academy of Sciences of the United States of America 109: 2139621401.

Martinelli, A.G. 2003. New cranial remains of Comahuesuchus brachybuccalis (Archosauria, Crocodyliformes) from the Late Cretaceous of Río Negro province, Argentina. Ameghiniana 40(4): 559-572.

Martinelli, A.G. \& D. Pais. 2008. A new baurusuchid crocodyliform (Archosauria) from the Late Cretaceous of Patagonia (Argentina). Comptes Rendus Palevol 7: 371-381.

Martinelli, A.G. \& E.I. Vera 2007. Achillesaurus manazzonei, a new alvarezsaurid theropod (Dinosauria) from the Late Cretaceous Bajo de la Carpa Formation, Río Negro Province, Argentina. Zootaxa 1582: 1-17.

Martinelli, A.G. \& V.P.A. Teixeira. 2015. The Late Cretaceous vertebrate record from the Bauru Group at the Triângulo Mineiro, southeastern Brazil. Boletín Geológico y Mineiro 126(1): 129-158.

Martinelli, A.G., J.J.W. Sertich, A.C. Garrido \& A.M. Praderio. 2012. A new peirosaurid from the Late Cretaceous of Argentina: implications for specimens referred to Peirosaurus torminni Price (Crocodyliformes: Peirosauridae). Cretaceous Research 37: 191-200.

Méndez, A.H., L.S. Filippi, F.A. Gianechini \& R.D. Juárez Valieri. 2018. New brachyrostran remains (Theropoda, Abelisauridae) from La Invernada fossil site (Bajo de la Carpa Formation, Upper Cretaceous), northern Patagonia, Argentina. Cretaceous Research 83: 120-126.

Milner, A.C., A.R. Milner \& S.E. Evans. 2000. Global changes and biota: amphibians, reptiles and birds. In: S. Culver \& P. Rawson (eds.), Biotic response to global change: the last 145 million years, pp. 316332, Cambridge University Press, Cambridge, UK.

Nava, W.R. \& A.G. Martinelli. 2011. A new squamate lizard from the Upper Cretaceous Adamantina Formation (Bauru Group), São Paulo State, Brazil. Anais da Academia Brasileira de Ciências 83(1): 
291-299.

Nydam, R.L. \& R.L. Cifelli. 2002. A new teiid lizard from the Cedar Mountain Formation (AlbianCenomanian boundary) of Utah. Journal of Vertebrate Paleontology 22: 276-285.

Nydam, R.L., J.A. Gauthier \& J.J. Chiment. 2000. The mammal-like teeth of the Late Cretaceous lizard Peneteius aquilonius Estes 1969 (Squamata, Teiidae). Journal of Vertebrate Paleontology 20: 628-631.

Nydam, R.L., J.G. Eaton \& J. Sankey. 2007. New taxa of transversely-toothed lizards (Squamata: Scincomorpha) and new information on the evolutionary history of 'teiids'. Journal of Vertebrate Paleontology 81: 538-549.

O’Leary, M.A., J.I. Bloch, J.J. Flynn, T.J. Gaudin, A. Giallombardo, N.P. Giannini, S.L. Goldberg, B.P. Kraatz, Z.-X Luo, J. Meng, X. Ni, M.J. Novacek, F.A. Perini, Z.S. Randall, G.W. Rougier, E.J. Sargis, M.T. Silcox, N.B. Simmons, M. Spaulding, P.M. Velazco, M. Weksler, J.R. Wible \& A.L. Cirranello. 2013. The placental mammal ancestor and the post-K-Pg radiation of placentals. Science 339: 662-667.

Oppel, M. 1811. Die Ordnungen, Familien, und Gattungen der Reptilien als Prodrom einer Naturgeschichte derselben. J. Lindauer, München, $86 \mathrm{pp}$.

Osborn, H.F. 1903. On the primary division of the Reptilia into two sub-classes, Synapsida and Diapsida. Science 17(424): 275-276.

Pol, D. 2005. Postcranial remains of Notosuchus terrestris Woodward (Archosauria: Crocodyliformes) from the Upper Cretaceous of Patagonia, Argentina. Ameghiniana 42(1): 21-38.

Pol, D. \& I.H. Escapa. 2009. Unstable taxa in cladistic analysis: identification and the assessment of relevant characters. Cladistics 25: 1-13.

Porfiri, J.D., R.D. Juarez Vallieri, D.D.D. Santos \& M.C. Lamanna. 2018 A new megaraptoran theropod dinosaur from the Upper Cretaceous Bajo de la Carpa Formation of northwestern Patagonia. Cretaceous Research 89: 302-319.

Presch, W. 1974. A survey of the dentition of the macroteiid lizards (Teiidae: Lacertilia). Herpetologica 30: 344-349.

Pyron, R.A. 2017. Novel approaches for phylogenetic inference from morphological data and total-evidence dating in squamate reptiles (lizards, snakes, and amphisbaenians). Systematic Biology 66: 38-56.

Ramos, V.A. 1981. Descripción Geológica de la Hoja 33c, Los Chihuidos Norte. Provincia del Neuquén. Servicio Geológico Nacional. Boletín 182: 1-103. Buenos Aires.

Reeder, T.W., T.M. Townsend, D.G. Mulcahy, B.P. Noonan, P.L. Wood, Jr.,J.W. Sites, Jr. \& J.J. Wiens. 2015. Integrated analyses resolve conflicts over squamate reptile phylogeny and reveal unexpected placements for fossil taxa. PLoS ONE 10(3): e0118199.

Richter, A. 1994. Lacertilia aus der Unteren Kreide von Uña und Galve (Spanien) und Anoual (Marokko). Berliner Geowissenschaftliche Abhandlungen (E)
14: 1-147.

Rodríguez, M.F., H.A. Leanza \& M. Salvarredy Aranguren. 2007. Hoja Geológica 3969-II Neuquén, provincias del Neuquén, Río Negro y La Pampa. Instituto de Geología y Recursos Naturales. SEGEMAR. Boletín 370: 1-165. Buenos Aires.

Romo de Vivar, P.R., A.G. Martinelli, P.H.M. Fonseca \& M.B. Soares. 2020. To be or not to be: The hidden side of Cargninia enigmatica and other puzzling remains of Lepidosauromorpha from the Upper Triassic of Brazil. Journal of Vertebrate Paleontology 40(4): e1828438-2.

Ross, C.E, H.-D. Sues \& W.J. de Klerk. 1999. Lepidosaurian remains from the Lower Cretaceous Kirkwood Formation of South Africa. Journal of Vertebrate Paleontology 19: 21-27.

Sánchez, M.L., M.J. Gómez \& S. Heredia. 2006. Sedimentología y paleoambientes del Subgrupo Río Colorado (Cretácico Superior), Grupo Neuquén, en las bardas de la ciudad de Neuquén y alrededores. Revista de la Asociación Geológica Argentina 61(2): 236-255.

Savage, J.M. 1966. The origins and history of the Central American herpetofauna. Copeia 1966(4): 719-766.

Schweitzer, M.H., F.D. Jackson, L.M. Chiappe, J.G. Schmitt, J.O. Calvo \& D. Rubilar-Rogers. 2002. Late Cretaceous avian eggs with embryos from Argentina. Journal of Vertebrate Paleontology 22(1): 191-195.

Scotese, C.R. 2013. Map Folio 17, Late Cretaceous, (Maastrichtian, $68 \mathrm{Ma}$ ). PALEOMAP PaleoAtlas for ArcGIS, volume 2, Cretaceous Paleogeographic, Paleoclimatic and Plate Tectonic Reconstructions, PALEOMAP Project, Evanston, IL.

Simões, T.R. 2012. Redescription of Tijubina pontei, an Early Cretaceous lizard (Reptilia; Squamata) from the Crato Formation of Brazil. Anais da Academia Brasileira de Ciências 84: 79-93.

Simões, T.R. \& R.A. Pyron. 2021. The squamate tree of life. Bulletin of the Museum of Comparative Zoology 163(2): 47-95.

Simões, T.R., M.W. Caldwell \& A.W.A. Kellner. 2015a. A new Early Cretaceous lizard species from Brazil, and the phylogenetic position of the oldest known South American squamates. Journal of Systematic Palaeontology 13: 601-614.

Simões, T.R., E. Wilner, M.W. Caldwell, L.C. Weinschütz, \& A.W.A. Kellner. 2015b. A stem acrodontan lizard in the Cretaceous of Brazil revises early lizard evolution in Gondwana. Nature Communications 6: 9149.

Simões, T.R., M.W. Caldwell, L.C. Weinschütz, E. Wilner \& A.W.A. Kellner. 2017. Mesozoic lizards from Brazil and their role in early squamate evolution in South America. Journal of Herpetology 51: 307-315.

Simões, T.R., M.W. Caldwell, M. Tałanda, M. Bernardi, A. Palci, O. Vernygora, F. Bernardini, L. Mancini \& R.L. Nydam. 2018. The origin of squamates revealed by a Middle Triassic lizard from the Italian Alps. Nature 557: 706-709. 
Smith, K.T. 2009. Eocene lizards of the Clade Geiseltaliellus from Messel and Geiseltal, Germany, and the early radiation of Iguanidae (Reptilia: Squamata). Bulletin of the Peabody Museum of Natural History 50: 219-306.

Sues, H.-D. 2019. The Rise of Reptiles: 320 million years of Evolution. Johns Hopkins University Press, Baltimore, $393 \mathrm{pp}$.

Uetz, P., P. Freed \& J. Hošek (eds.) 2020. The Reptile Database, http://www.reptile-database.org, Accessed 2021.

Woolley, C.H., N.D. Smith \& J.J.W. Sertich. 2020. New fossil lizard specimens from a poorly-known squamate assemblage in the Upper Cretaceous (Campanian) San Juan Basin, New Mexico, USA. PeerJ 8: e8846.
Woodward, A.S. 1896. On two Mesozoic crocodilians Notosuchus nov. gen. and Cynodontosuchus nov. gen. from the red sandstones of the Territory of Neuquén (Argentina). Anales del Museo de la Plata, Paleontología 4: 1-20.

Woodward, A.S. 1901. On some extinct reptiles from Patagonia of the genera Miolania, Dinilysia and Genyodectes. Proceeding of the Zoological Society 1901: 169-184.

Zils, W., C. Werner, A. Moritz \& C. Saanane. 1995. Tendagaru, the most famous dinosaur locality of Africa. Review, survey and future prospects. Documenta Naturae, Munich 97: 1-41.

Zug, G.R., L.J. Vitt \& J.P. Caldwell. 2001. Herpetology, an introductory biology of amphibians and reptiles. Academic Press, San Diego CA, USA, 630 pp.

Doi: 10.22179/REVMACN.23.716

Recibido: 28-III-2021

Aceptado: 15-VII-2021 